\title{
Kinetic and mechanistic study of the reaction between methane sulfonamide $\left(\mathrm{CH}_{3} \mathrm{~S}(\mathrm{O})_{2} \mathrm{NH}_{2}\right)$ and $\mathrm{OH}$
}

\author{
Matias Berasategui, Damien Amedro, Achim Edtbauer, Jonathan Williams, Jos Lelieveld, and John N. Crowley \\ Division of Atmospheric Chemistry, Max-Planck-Institut für Chemie, 55128 Mainz, Germany
}

Correspondence: John N. Crowley (john.crowley@mpic.de)

Received: 8 November 2019 - Discussion started: 28 November 2019

Revised: 30 January 2020 - Accepted: 3 February 2020 - Published: 4 March 2020

\begin{abstract}
Methane sulfonamide (MSAM), $\mathrm{CH}_{3} \mathrm{~S}(\mathrm{O})_{2} \mathrm{NH}_{2}$, was recently detected for the first time in ambient air over the Red Sea and the Gulf of Aden where peak mixing ratios of $\approx 60 \mathrm{pptv}$ were recorded. Prior to this study the rate constant for its reaction with the $\mathrm{OH}$ radical and the products thereby formed were unknown, precluding assessment of its role in the atmosphere. We have studied the $\mathrm{OH}$-initiated photooxidation of MSAM in air (298 K, 700 Torr total pressure) in a photochemical reactor using in situ detection of MSAM and its products by Fourier transform infrared (FTIR) absorption spectroscopy. The relative rate technique, using three different reference compounds, was used to derive a rate coefficient of $(1.4 \pm 0.3) \times 10^{-13} \mathrm{~cm}^{3}$ molec. ${ }^{-1} \mathrm{~s}^{-1}$. The main end products of the photo-oxidation observed by FTIR were $\mathrm{CO}_{2}, \mathrm{CO}, \mathrm{SO}_{2}$, and $\mathrm{HNO}_{3}$ with molar yields of $(0.73 \pm 0.11)$, $(0.28 \pm 0.04),(0.96 \pm 0.15)$, and $(0.62 \pm 0.09)$, respectively. $\mathrm{N}_{2} \mathrm{O}$ and $\mathrm{HC}(\mathrm{O}) \mathrm{OH}$ were also observed in smaller yields of $(0.09 \pm 0.02)$ and $(0.03 \pm 0.01)$. Both the low rate coefficient and the products formed are consistent with hydrogen abstraction from the $-\mathrm{CH}_{3}$ group as the dominant initial step. Based on our results MSAM has an atmospheric lifetime with respect to loss by reaction with $\mathrm{OH}$ of about $80 \mathrm{~d}$.
\end{abstract}

\section{Introduction}

Natural emissions of organosulfur compounds from phytoplankton comprise up to $60 \%$ of the total sulfur flux into the marine boundary layer (Andreae, 1990; Bates et al., 1992; Spiro et al., 1992), and in remote oceanic areas they are the main source of climatically active sulfate aerosols, which can influence the radiation balance at the earth's surface (Charlson et al., 1987; Andreae and Crutzen, 1997).
The main organosulfur trace gases in the marine boundary layer are dimethyl sulfide $\left(\mathrm{CH}_{3} \mathrm{SCH}_{3}\right.$, DMS $)$ and its oxidation products dimethyl sulfoxide (DMSO), dimethyl sulfone $\left(\mathrm{DMSO}_{2}\right)$, methyl sulfonic acid (MSA), and methyl sulfinic acid (MSI) for which atmospheric lifetimes with respect to their degradation by the $\mathrm{OH}$ radical vary between hours (DMS) and several weeks ( $\left.\mathrm{DMSO}_{2}\right)$.

Recently, the first detection of methane sulfonamide $\left(\mathrm{CH}_{3} \mathrm{~S}(\mathrm{O})_{2} \mathrm{NH}_{2}, \mathrm{MSAM}\right)$ in ambient air was made during the Air Quality and Climate Change in the Arabian Basin (AQABA-2017) campaign. Mixing ratios of MSAM approached 60 pptv over the Arabian Sea; details of these measurements and a discussion of the likely sources of MSAM in these regions are given in a companion paper (Edtbauer et al., 2019). As MSAM had not been considered to be an atmospheric trace gas prior to the observations of Edtbauer et al. (2019), there have been no laboratory studies to investigate either its spectroscopy or the kinetics of its reactions with atmospheric radicals, such as $\mathrm{OH}$, so that its atmospheric lifetime and the products formed during its degradation in air were unknown. Combining carbon, nitrogen, sulfur, and oxygen in a single, small molecule, MSAM is an intriguing species not only as an atmospheric trace gas but also from a spectroscopic and kinetic perspective. Unlike basic alkyl amines such as, for example, $\mathrm{CH}_{3} \mathrm{NH}_{2}$, MSAM contains an acidic $-\mathrm{NH}_{2}$ group (Remko, 2003).

This work presents the first kinetic and mechanistic study of the $\mathrm{OH}$-induced oxidation of MSAM in air. A reaction mechanism is proposed that, through numerical simulation, describes the time-dependent formation of the end products we observed. From these results, we calculate the lifetime and the likely role of MSAM in the atmosphere. 


\section{Methods}

\subsection{Experimental set-up}

The experimental set-up used to study the reaction of $\mathrm{OH}$ with MSAM has been described in detail previously (Crowley et al., 1999; Bunkan et al., 2018). Briefly, the reaction vessel was a $44.39 \mathrm{~L}$ cylindrical quartz-wall chamber equipped with a White-type multiple-reflection mirror system resulting in an $86.3 \mathrm{~m}$ optical path length for absorption spectroscopy in the infrared. The quartz reactor was at room temperature $(296 \pm 2 \mathrm{~K})$ and for most experiments at 700 Torr total pressure $(1 \mathrm{Torr}=1.333 \mathrm{hPa})$ using synthetic air bath gas. Six external, radially mounted, low-pressure Hg lamps emitting mainly at $253.65 \mathrm{~nm}$ provided a homogeneous light flux within the reactor for radical generation. A 1000 Torr capacitance manometer was used to measure the pressure inside the reactor.

MSAM and other gases used to generate $\mathrm{OH}$ (see below) were mixed in a glass vacuum line which was connected directly to the reaction chamber by a PTFE piping. Two capacitance manometers (10 and 100 Torr ranges) were used to accurately measure pressures in the vacuum line. Crystalline MSAM melts at $363 \mathrm{~K}$ and has a boiling point of approximately $453 \mathrm{~K}$ and an unknown vapour pressure ( $<0.02$ Torr) at room temperature. Owing to its low vapour pressure, MSAM was eluted into the reaction chamber by

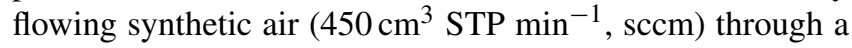
finger containing crystalline MSAM warmed to $333 \mathrm{~K}$ and subsequently through a cold trap at $298 \mathrm{~K}$ (to prevent condensation downstream). This way we could ensure that the saturation vapour pressure of MSAM at $298 \mathrm{~K}$ was achieved. In initial experiments without the trap we observed extra absorption features, which could be assigned to a dimer of MSAM (see below).

Gas-phase infrared spectra in the range of $4000-600 \mathrm{~cm}^{-1}$ were recorded with a resolution of $2 \mathrm{~cm}^{-1}$ from 16 coadded interferograms (128 scans for the background) using a Fourier transform infrared (FTIR) spectrometer (Bruker Vector 22) equipped with an external photoconductive mercurycadmium-telluride (MCT) detector cooled to liquid nitrogen temperature. OPUS software was used to analyse and manipulate the IR spectra. Interferograms were phase-corrected (Mertz) and Boxcar apodized with a zero-filling factor of 4 . Most of the products obtained $\left(\mathrm{CO}_{2}, \mathrm{CO}, \mathrm{HC}(\mathrm{O}) \mathrm{OH}, \mathrm{HNO}_{3}\right.$, and $\mathrm{SO}_{2}$ ) were identified and quantified from the IR reference spectra of pure samples under similar experimental conditions (700 Torr and 298.2 K, Fig. S1 in the Supplement).

The low vapour pressure of MSAM precluded accurate dosing into the chamber and thus generation of a calibration spectrum. In order to calibrate the infrared absorption features of MSAM, we oxidized it in air and then conducted a sulfur and nitrogen balance of the products. As discussed below, the only sulfur-containing product detected from MSAM degradation was $\mathrm{SO}_{2}$ (which can easily be calibrated), and the only nitrogen-containing products were $\mathrm{HNO}_{3}$ and $\mathrm{N}_{2} \mathrm{O}$, which can also be calibrated. Experiments in which MSAM was almost completely converted to known amounts of $\mathrm{SO}_{2}, \mathrm{HNO}_{3}$, and $\mathrm{N}_{2} \mathrm{O}$ thus provided an indirect calibration (via assumption of $100 \%$ sulfur or nitrogen balance) of its concentration and thus IR cross sections.

\subsection{Generation of $\mathrm{OH}$}

$\mathrm{OH}$ was generated by the $254 \mathrm{~nm}$ photolysis of $\mathrm{O}_{3}$ in the presence of $\mathrm{H}_{2}$.

$$
\begin{aligned}
& \mathrm{O}_{3}+h v(254 \mathrm{~nm}) \rightarrow \mathrm{O}\left({ }^{1} \mathrm{D}\right)+\mathrm{O}_{2} \\
& \mathrm{O}\left({ }^{1} \mathrm{D}\right)+\mathrm{H}_{2} \rightarrow \mathrm{OH}+\mathrm{H} \\
& \mathrm{H}+\mathrm{O}_{2}+\mathrm{M} \rightarrow \mathrm{HO}_{2}+\mathrm{M}
\end{aligned}
$$

Further reactions that cycle $\mathrm{OH}$ and $\mathrm{HO}_{2}$ (e.g. $\mathrm{OH}+\mathrm{H}_{2}, \mathrm{H}+$ $\mathrm{O}_{3}, \mathrm{HO}_{2}+\mathrm{O}_{3}$ ) are listed in Table $\mathrm{S} 1$ in the Supplement.

In a typical experiment, the starting concentrations of $\mathrm{O}_{3}$ and $\mathrm{H}_{2}$ were $\approx 5 \times 10^{14}$ and $\approx 5-7 \times 10^{15}$ molec. $\mathrm{cm}^{-3}$. As described previously (Bunkan et al., 2018), this scheme generates not only $\mathrm{OH}$ radicals but also via, for example, Reaction (R3) $\mathrm{HO}_{2} . \mathrm{HO}_{2}$ is not expected to react with MSAM but will influence the course of secondary reactions in this system (e.g. by reacting with organic peroxy radicals) and thus the end-product distribution, as described in detail in Sect. 3.5. Simulations of the radical concentrations when generating $\mathrm{OH}$ in this manner indicate that the $\mathrm{HO}_{2} / \mathrm{OH}$ ratio is approximately 30 , with individual concentrations of $\approx 1 \times 10^{11}$ molec. $\mathrm{cm}^{-3} \mathrm{HO}_{2}$ and $3 \times 10^{9}$ molec. $\mathrm{cm}^{-3} \mathrm{OH}$.

As an $\mathrm{OH}$ source, the photolysis of $\mathrm{O}_{3}$ in the presence of $\mathrm{H}_{2}$ has the advantage over other photochemical sources (e.g. photolysis of $\mathrm{H}_{2} \mathrm{O}_{2}, \mathrm{HONO}$, or $\mathrm{CH}_{3} \mathrm{ONO}$ ) that neither $\mathrm{H}_{2}$ nor $\mathrm{O}_{3}$ has strong absorption features in the infrared, resulting in a less cluttered spectrum which simplifies retrieval of concentration-time profiles of reactants and products.

\subsection{Chemicals}

A commercially available sample of methane sulfonamide (Alfa Aesar, $>98 \%$ ) was used. $\mathrm{O}_{3}$ was generated by flowing synthetic air (Westfalen) through a stainless-steel tube that housed a low-pressure Hg lamp (PenRay) emitting at $184.95 \mathrm{~nm}$. Synthetic air (Westfalen, $99.999 \%), \mathrm{H}_{2}$ (Westfalen, 99.999\%), $\mathrm{CO}_{2}$ (Westfalen 99.995\%), $\mathrm{CO}$ (Westfalen, $99.997 \%$ ), $\mathrm{SO}_{2}$ (Air Liquide, $1 \mathrm{ppmv}$ in air), and $\mathrm{HC}(\mathrm{O}) \mathrm{OH}$ (Sigma Aldrich) were obtained commercially. Anhydrous nitric acid was prepared by mixing $\mathrm{KNO}_{3}$ (Sigma Aldrich, 99\%) and $\mathrm{H}_{2} \mathrm{SO}_{4}$ (Roth, 98\%) and condensing $\mathrm{HNO}_{3}$ vapour into a liquid nitrogen trap.

\subsection{Relative rate constant determination}

The rate constant $\left(k_{4}\right)$ of the reaction between $\mathrm{OH}$ and $\mathrm{CH}_{3} \mathrm{SO}_{2} \mathrm{NH}_{2}$ (Reaction R4) was measured using the relative rate method using (in different experiments) formic 
acid $(\mathrm{HC}(\mathrm{O}) \mathrm{OH})$, acetone $\left(\mathrm{CH}_{3} \mathrm{C}(\mathrm{O}) \mathrm{CH}_{3}\right)$, and methanol $\left(\mathrm{CH}_{3} \mathrm{OH}\right)$ as reference compounds.

$$
\begin{aligned}
& \mathrm{CH}_{3} \mathrm{~S}(\mathrm{O})_{2} \mathrm{NH}_{2}+\mathrm{OH} \rightarrow \text { products } \\
& \mathrm{CH}_{3} \mathrm{C}(\mathrm{O}) \mathrm{CH}_{3}+\mathrm{OH} \rightarrow \text { products } \\
& \mathrm{HC}(\mathrm{O}) \mathrm{OH}+\mathrm{OH} \rightarrow \text { products } \\
& \mathrm{CH}_{3} \mathrm{OH}+\mathrm{OH} \rightarrow \text { products }
\end{aligned}
$$

Relative rate constants were derived by monitoring the depletion of one or more IR features of MSAM relative to those of the reference compounds. The following expression links the depletion factors (e.g. $\ln \left([\mathrm{MSAM}]_{0} /[\mathrm{MSAM}]_{t}\right)$ ) to the relative rate coefficient:

$\ln \left(\frac{[\mathrm{MSAM}]_{0}}{[\mathrm{MSAM}]_{t}}\right)=\frac{k_{4}}{k_{\mathrm{ref}}} \ln \left(\frac{[\mathrm{ref}]_{0}}{[\mathrm{ref}]_{t}}\right)$

where $[\mathrm{MSAM}]_{0},[\mathrm{MSAM}]_{t},[\mathrm{ref}]_{0}$, and $[\mathrm{ref}]_{t}$ are the concentrations of MSAM and reference compound at times 0 and $t ; k_{4}$ and $k_{\text {ref }}$ are the rate constants for reactions of $\mathrm{OH}$ with the MSAM and reference, respectively. As only relative changes in the IR signal are used in the analysis, absolute concentrations are not required as long as the absorption features used display a linear relation with concentration. Plots of $\ln \left([\mathrm{MSAM}]_{0} /[\mathrm{MSAM}]_{t}\right)$ versus $\ln \left([\mathrm{ref}]_{0} /[\mathrm{ref}]_{t}\right)$ should therefore be linear, pass through the origin, and have a slope of $k_{4} / k_{\text {ref }}$. The experimental procedure consisted of filling the cell with a mixture of MSAM/reference $/ \mathrm{O}_{3} / \mathrm{H}_{2} / \mathrm{N}_{2}$ and allowing it to $\operatorname{mix}(5-10 \mathrm{~min}$ ) prior to subjecting the mixture to $253.65 \mathrm{~nm}$ radiation whilst monitoring IR features at 35 min intervals.

This analysis inherently assumes that the only loss process for MSAM and the reference molecules is reaction with $\mathrm{OH}$. Experiments in which the starting gas mixture was allowed to stand for several hours with no discernible loss of MSAM, formic acid, methanol, or acetone confirmed that none of these gases are lost to the wall or react with $\mathrm{O}_{3}$ to a significant extent. From observation of MSAM and $\mathrm{O}_{3}$ mixtures, we were able to derive an upper limit for the reaction of MSAM with $\mathrm{O}_{3}$ of $1 \times 10^{-19} \mathrm{~cm}^{3}$ molec. ${ }^{-1} \mathrm{~s}^{-1}$.

\section{Results and discussion}

\subsection{Vibrational characterization of $\mathrm{CH}_{3} \mathrm{SO}_{2} \mathrm{NH}_{2}$}

The experimental, infrared absorption spectrum of MSAM (Fig. 1) shows characteristic bands corresponding to $\mathrm{SO}_{2}$ stretching vibrations at 1385 and $1172 \mathrm{~cm}^{-1}$, the $\mathrm{NH}_{2}$ wagging vibration at $857 \mathrm{~cm}^{-1}$, stretching vibrations at 3476 and $3380 \mathrm{~cm}^{-1}$, bending at $1551 \mathrm{~cm}^{-1}$, and the $\mathrm{CH}_{3}$ wagging band at $976 \mathrm{~cm}^{-1}$. Assignment of the infrared features (Table 1) was made by comparison with a theoretical spectrum calculated using density functional theory (DFT) at the B3LYP/6-311++G(3d,2p) and B3LYP/aug-cc-pVTZ$\mathrm{pp}$ levels of theory for the vibrational characterization of

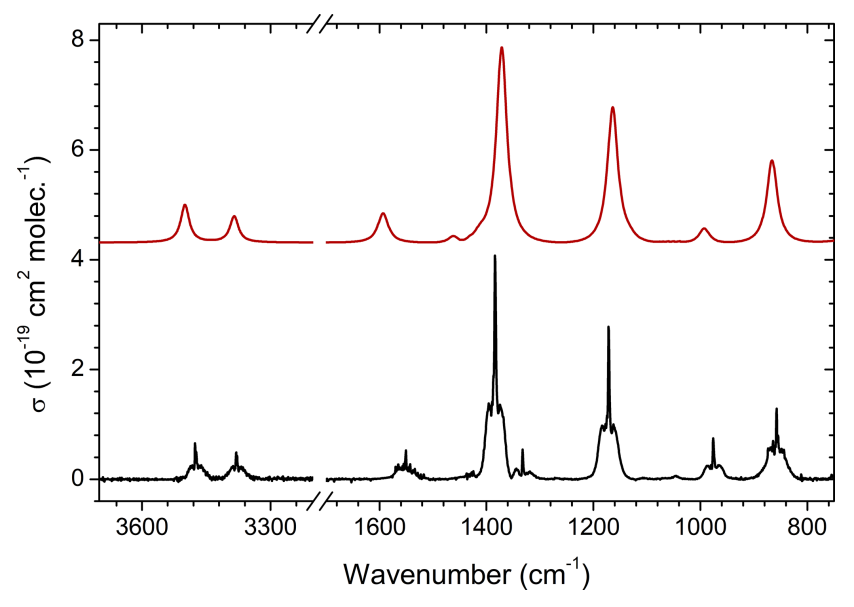

Figure 1. Comparison of the experimental infrared absorption spectrum (black line) of MSAM $\left(\sim 1 \times 10^{14}\right.$ molec. $\left.\mathrm{cm}^{-3}\right)$ and the calculated spectrum at B3LYP/aug-cc-pVTZ-pp levels of theory (red line). The cross sections $(\sigma)$ are in base e.

MSAM in the gas phase. These basis sets should be sufficient to describe the relative energies for the isomers. Harmonic vibrational frequencies and zero-point energies (ZPEs) were calculated at these levels of theory to check whether the stationary points obtained were either isomers or first-order transition states (all calculated conformers had only real frequencies). The high-accuracy energy method Gaussian 04 with Møller-Plesset expansion truncated at the second order (G4MP2) was also used for the calculation of the barrier energies. The determination of the Hessian matrix also enabled the calculation of the thermochemical quantities for the conformers at $298.15 \mathrm{~K}$. All symmetry restrictions were turned off in the calculations. All calculations were run with the Gaussian 09 program package (Frisch, 2009). Assuming that the point group for the molecule is Cs, all 24 fundamental modes should be both IR and Raman active, 14 of them belonging to $\mathrm{A}^{\prime}$ representation and 10 to $\mathrm{A}^{\prime \prime}$. All the vibrational frequencies are real and positive. The assignments in Table 1 were made from an evaluation of the normal-mode displacement vectors; as many of the modes are strongly coupled, this information is rather subjective. The frequencies of the absorption bands of the theoretical spectrum displayed in Fig. 1 were adjusted by a scaling factor of $0.968 \pm 0.019$ recommended for the B3LYP/aug-cc-pVTZ level of theory (column "ratio" in Table 1) (Halls et al., 2001).

If the "cold trap" is removed, extra absorption bands originating from the MSAM dimer are observed. These slowly disappear with time as the condensation of the low-volatility dimer to the reactor surfaces takes place. Figure $\mathrm{S} 1$ shows the IR spectra of the dimer after the subtraction of the monomer. A complete characterization of the vibrational modes is presented in Table S1. According to our calculations, two hydrogen-bond interactions between the $-\mathrm{HNH}$...OSO- are formed in the dimer which produce a bathochromic shift of 
Table 1. Experimental and calculated vibrational wavenumbers for MSAM.

\begin{tabular}{|c|c|c|c|c|c|c|}
\hline \multirow[t]{2}{*}{ Mode symm. } & \multirow[t]{2}{*}{ Mode } & \multicolumn{4}{|c|}{ Frequencies $\left(\mathrm{cm}^{-1}\right)$} & \multirow[t]{2}{*}{ Mode description } \\
\hline & & Experiment $^{\mathrm{a}}$ & $6-31++(d, p)^{a, b}$ & Aug-CC-pVTZ a,b & Ratio & \\
\hline \multirow[t]{10}{*}{$\mathrm{A}^{\prime \prime}$} & $v_{1}$ & $3476(18.8)$ & 3627 (18.8) & 3612 (19.6) & 0.958 & $\mathrm{NH}_{2}$ asym. stretch \\
\hline & $v_{3}$ & & $3193(<0.1)$ & $3169(0.2)$ & & $\mathrm{CH}_{3}$ deformation \\
\hline & $v_{7}$ & & $1461(1.1)$ & $1457(0.4)$ & & $\mathrm{CH}_{3}$ rocking \\
\hline & $v_{10}$ & $1383(100)$ & $1322(100)$ & $1342(100)$ & 1.048 & $\mathrm{SO}_{2}$ asym. stretch \\
\hline & $v_{12}$ & & $1085(2.2)$ & $1087(1.5)$ & & $\mathrm{NH}_{2}$ rocking \\
\hline & $v_{14}$ & & $981(0.3)$ & $972(0.3)$ & & $\mathrm{CH}_{3}$ twisting \\
\hline & $v_{20}$ & & $385(<0.1)$ & $392(<0.1)$ & & $\mathrm{C}-\mathrm{S}-\mathrm{N}$ twist \\
\hline & $v_{21}$ & & $321(1.1)$ & $328(1.2)$ & & $\mathrm{C}-\mathrm{S}-\mathrm{N}$ twist \\
\hline & $v_{23}$ & & $218(0.2)$ & $216(1.5)$ & & $\mathrm{CH}_{3}$ twist \\
\hline & $v_{24}$ & & $170(14.9)$ & $179(11.2)$ & & $\mathrm{NH}_{2}$ twist \\
\hline \multirow[t]{14}{*}{$\mathrm{A}^{\prime}$} & $v_{2}$ & $3380(17.2)$ & $3512(13.0)$ & $3508(13.8)$ & 0.962 & $\mathrm{NH}_{2}$ sym. stretch \\
\hline & $v_{4}$ & & $3184(<0.1)$ & $3161(<0.1)$ & & $\mathrm{CH}_{3}$ asym. stretch \\
\hline & $v_{5}$ & & $3079(0.1)$ & $3065(<0.1)$ & & $\mathrm{CH}_{3}$ sym. stretch \\
\hline & $v_{6}$ & $1551(15.6)$ & $1591(15.2)$ & $1582(13.5)$ & 0.975 & $\mathrm{NH}_{2}$ bend \\
\hline & $v_{8}$ & & $1460(2.5)$ & $1456(1.9)$ & & $\mathrm{CH}_{3}$ asym. bend \\
\hline & $\nu_{9}$ & $1428(3.7)$ & $1363(3.3)$ & $1350(4.2)$ & 1.048 & $\mathrm{CH}_{3}$ umbrella \\
\hline & $v_{11}$ & $1172(72.8)$ & $1115(69.6)$ & 1135 (64.2) & 1.051 & $\mathrm{SO}_{2}$ sym. stretch \\
\hline & $v_{13}$ & $976(17.8)$ & 994 (7.6) & 987 (8.9) & 0.982 & $\mathrm{CH}_{3}$ wagging \\
\hline & $v_{15}$ & $857(43.1)$ & $867(42.4)$ & $864(40.8)$ & 0.988 & $\mathrm{NH}_{2}$ wagging \\
\hline & $v_{16}$ & & $704(7.2)$ & $704(4.2)$ & & C-S stretch \\
\hline & $v_{17}$ & & 663 (81.9) & $649(81.5)$ & & S-N stretch \\
\hline & $v_{18}$ & & 480 (14.9) & $490(15.8)$ & & $\mathrm{SO}_{2}$ wagging \\
\hline & $v_{19}$ & & $457(5.1)$ & $468(3.5)$ & & $\mathrm{SO}_{2}$ bend \\
\hline & $v_{22}$ & & $285(1.8)$ & 290 (1.9) & & $\mathrm{C}-\mathrm{S}-\mathrm{N}$ bend \\
\hline
\end{tabular}

a Relative absorbance at band maximum in parentheses. ${ }^{\mathrm{b}}$ Calculated using the B3LYP method.

the absorption bands. For each kinetic experiment we ensure that no dimer band is present in the initial spectrum.

\subsection{Relative rate measurements: determination of $\boldsymbol{k}_{4}$}

Once the concentrations of MSAM and the reference compound were stable (i.e. mixing in the chamber was complete) the photolysis lamps were switched on for a period of typically $1 \mathrm{~h}$ during which FTIR spectra (duration of $\sim 20 \mathrm{~s}$ ) were obtained every few minutes. The concentrations of the reactants in each individual experiment can be found in Table 2. Figure 2 shows the loss of absorption features due to MSAM and the reference compound (in this case acetone) at different times during the experiment.

The depletion of MSAM was quantified by integrating the Q-branch of the 857,1172 , and $1383 \mathrm{~cm}^{-1}$ absorption bands and the complete absorption band at $3380 \mathrm{~cm}^{-1}$. The relative depletion of the MSAM absorption features agreed to within $\sim 5 \%$. Depletion of the reference gases was quantified by integrating their absorption bands at $1221-1249 \mathrm{~cm}^{-1}$ (acetone), $2788-3070 \mathrm{~cm}^{-1}$ (methanol), and $1073-1133 \mathrm{~cm}^{-1}$ (formic acid). An alternative analysis procedure, in which the relative depletion of MSAM was derived by scaling a reference spectrum of MSAM (e.g. that obtained prior to photoly-

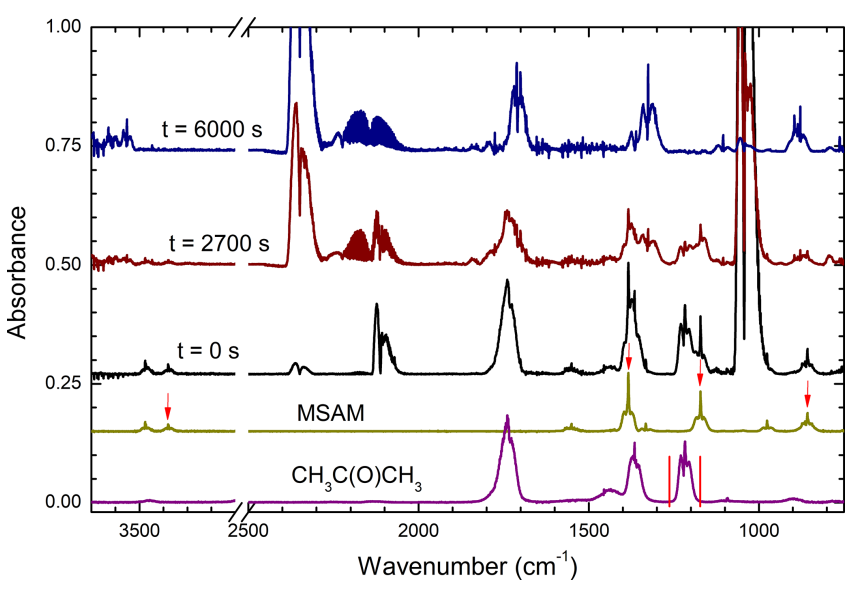

Figure 2. Raw data from a relative rate experiment (using acetone as reference reactant) showing the gradual depletion of reactants and formation of products. The lower two spectra are reference spectra, indicating (red arrows and red min-max lines) which absorption features were used for the relative rate analysis. The strong absorption close to $2100 \mathrm{~cm}^{-1}$ at $t=0 \mathrm{~s}$ is due to $\mathrm{O}_{3} \cdot \mathrm{CO}_{2}$ and $\mathrm{CO}$ absorption bands are centred at $\approx 2350$ and $2140 \mathrm{~cm}^{-1}$, respectively. 
Table 2. Rate coefficient ratios and experimental conditions for the relative rate experiments.

\begin{tabular}{|c|c|c|c|c|c|c|c|c|}
\hline \multirow{2}{*}{$\begin{array}{l}\text { Reference } \\
\text { reactant }^{\mathrm{a}}\end{array}$} & \multicolumn{4}{|c|}{ Concentration $\left(10^{14}\right.$ molec. $\left.\mathrm{cm}^{-3}\right)$} & \multirow{2}{*}{$\begin{array}{l}\text { Band }^{\mathrm{e}} \\
\left(\mathrm{cm}^{-1}\right)\end{array}$} & \multirow[t]{2}{*}{$k_{4} / k_{\mathrm{ref}}$} & \multirow{2}{*}{\multicolumn{2}{|c|}{$\begin{array}{c}k_{4} \\
\left(10^{-13} \mathrm{~cm}^{3} \text { molec. }^{-1} \mathrm{~s}^{-1}\right)\end{array}$}} \\
\hline & {$[\mathrm{MSAM}]^{\mathrm{b}}$} & {$[\operatorname{Ref}]^{\mathrm{c}}$} & {$\left[\mathrm{O}_{3}\right]^{\mathrm{d}}$} & {$\left[\mathrm{H}_{2}\right]^{\mathrm{c}}$} & & & & \\
\hline \multirow[t]{4}{*}{ Acetone } & 0.31 & 0.34 & 7.71 & 71.8 & 857 & $0.792 \pm 0.012$ & $1.43 \pm 0.10$ & $1.40 \pm 0.09^{f}$ \\
\hline & & & & & 1172 & $0.771 \pm 0.005$ & $1.39 \pm 0.09$ & \\
\hline & & & & & 1383 & $0.779 \pm 0.006$ & $1.40 \pm 0.09$ & \\
\hline & & & & & 3380 & $0.770 \pm 0.010$ & $1.39 \pm 0.10$ & \\
\hline \multirow[t]{3}{*}{ Formic acid } & 0.56 & 0.55 & 5.74 & 65.2 & 857 & $0.312 \pm 0.004$ & $1.41 \pm 0.11$ & $1.38 \pm 0.09^{f}$ \\
\hline & & & & & 1172 & $0.311 \pm 0.002$ & $1.40 \pm 0.10$ & \\
\hline & & & & & 1383 & $0.302 \pm 0.002$ & $1.36 \pm 0.10$ & \\
\hline \multirow[t]{3}{*}{ Methanol } & 0.88 & 0.25 & 4.58 & 46.6 & 1172 & $0.159 \pm 0.001$ & $1.43 \pm 0.17$ & $1.42 \pm 0.16^{\mathrm{f}}$ \\
\hline & & & & & 1383 & $0.153 \pm 0.001$ & $1.38 \pm 0.17$ & \\
\hline & & & & & 3380 & $0.161 \pm 0.003$ & $1.45 \pm 0.19$ & \\
\hline
\end{tabular}

\footnotetext{
a Depletion of reference reactants monitored at 1221-1249, 1073-1133, and $2788-3070 \mathrm{~cm}^{-1}$ for acetone, formic acid, and methanol, respectively.

${ }^{\mathrm{b}}$ Concentration estimated from the absorption cross section reported in Fig. 1. ${ }^{\mathrm{c}}$ Concentration calculated from the measured pressures.

${ }^{\mathrm{d}}$ Concentration derived from the absorption cross section of $\mathrm{O}_{3} .{ }^{\mathrm{e}} \mathrm{IR}$ absorption bands of MSAM used for the determination of the concentration

change over time. ${ }^{\mathrm{f}}$ Relative rate constant obtained from the linear fitting of all the data and using $k_{4}=(1.8 \pm 0.1) \times 10^{-13}$,

$k_{5}=(4.5 \pm 0.36) \times 10^{-13}$, and $k_{6}=(9.0 \pm 1.3) \times 10^{-13} \mathrm{~cm}^{3}$ molec. ${ }^{-1} \mathrm{~s}^{-1}$ rate constants (IUPAC, 2019).
}

sis) to match those at various times after photolysis, was also used. The depletion factors thus obtained were indistinguishable from those using individual absorption features.

Figure 3 shows plots of the depletion factors for MSAM versus those of the three reference compounds following exposure to $\mathrm{OH}$ radicals in 700 Torr of synthetic air at $296 \mathrm{~K}$. A linear least-squares analysis of the data gives rate constant ratios $k_{4} / k_{5}=(0.778 \pm 0.008), k_{4} / k_{6}=(0.307 \pm 0.004)$, and $k_{4} / k_{7}=(0.158 \pm 0.002)$ where the quoted errors are 2 standard deviations. Table 2 summarizes the experimental conditions and the rate coefficient ratios obtained when using each MSAM absorption band. The difference between the rate coefficient ratios obtained for the three-absorption-band experiments is always less than $5 \%$. The rate constant ratios were placed on an absolute basis using evaluated rate coefficients (Atkinson et al., 2006; IUPAC, 2019) whereby $k_{5}=(1.8 \pm 0.36) \times 10^{-13}, k_{6}=(4.5 \pm 1.8) \times 10^{-13}$ and $k_{7}=$ $(9.0 \pm 1.8) \times 10^{-13} \mathrm{~cm}^{3}$ molec. $^{-1} \mathrm{~s}^{-1}$. We derive values of $k_{4}$ (relative to acetone) $=(1.40 \pm 0.28) \times 10^{-13}, k_{4}$ (relative to formic acid) $=(1.38 \pm 0.55) \times 10^{-13}$, and $k_{4}$ (relative to methanol $)=(1.42 \pm 0.28) \times 10^{-13} \mathrm{~cm}^{3}$ molec. ${ }^{-1} \mathrm{~s}^{-1}$ (where the uncertainties include uncertainty associated with the evaluated rate coefficients for $k_{5}, k_{6}$, and $k_{7}$ ). The values of $k_{4}$ obtained using the three different reference compounds are, within experimental uncertainties, identical, indicating the absence of significant systematic errors associated with the use of the reference reactants. We prefer the value of $k_{4}$ from the experiment using acetone as reference. For acetone, the relative rate constant is close to unity and the rate coefficient for $\mathrm{OH}$ has been extensively studied and is associated with low uncertainty. The preferred value of the rate coefficient, $k_{4}$, is $(1.4 \pm 0.3) \times 10^{-13} \mathrm{~cm}^{3}$ molec. ${ }^{-1} \mathrm{~s}^{-1}$ where the uncertainty is $2 \sigma$.

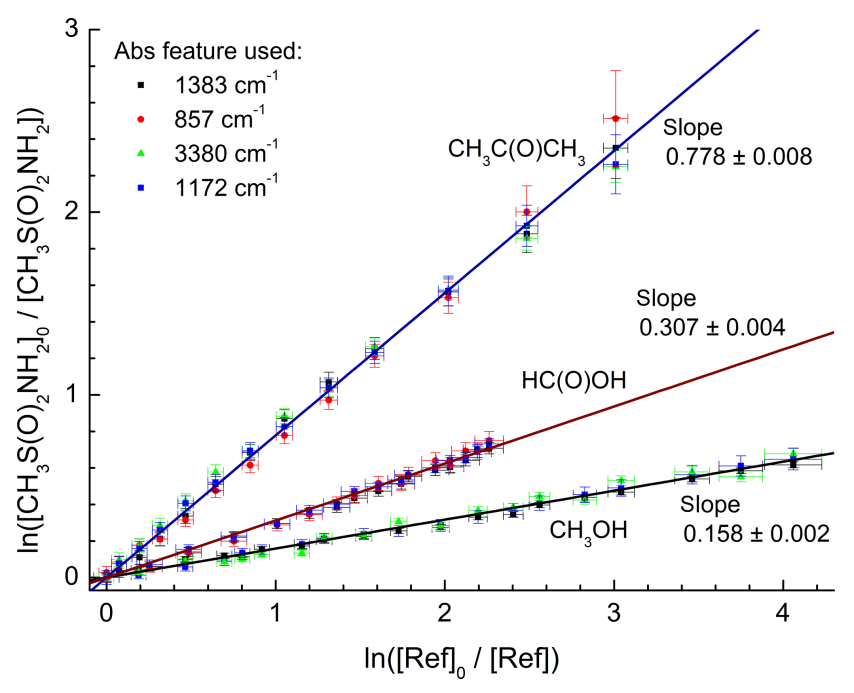

Figure 3. Relative depletion factors for MSAM and the reference compounds $\mathrm{CH}_{3} \mathrm{C}(\mathrm{O}) \mathrm{CH}_{3}, \mathrm{HC}(\mathrm{O}) \mathrm{OH}$, and $\mathrm{CH}_{3} \mathrm{OH}$ obtained at room temperature and a total pressure of 700 Torr of air. The different absorption bands of MSAM used in the analysis are indicated. The slopes are equal to the ratio of rate coefficients $k_{4} / k_{\text {ref }}$ as defined in Eq. (1).

\subsection{Product yields}

In order to identify and quantify the end products of the title reaction in air, approximately $(6.25 \pm 0.75) \times$ $10^{13}$ molec. $\mathrm{cm}^{-3}$ of MSAM, $4.04 \times 10^{14}$ molec. $\mathrm{cm}^{-3}$ of $\mathrm{O}_{3}$, and $1.00 \times 10^{15}$ molec. $\mathrm{cm}^{-3}$ of $\mathrm{H}_{2}$ were loaded into the chamber at a total pressure of 700 Torr of synthetic air and 298 K. Subsequent to initiation of the reaction between $\mathrm{OH}$ 


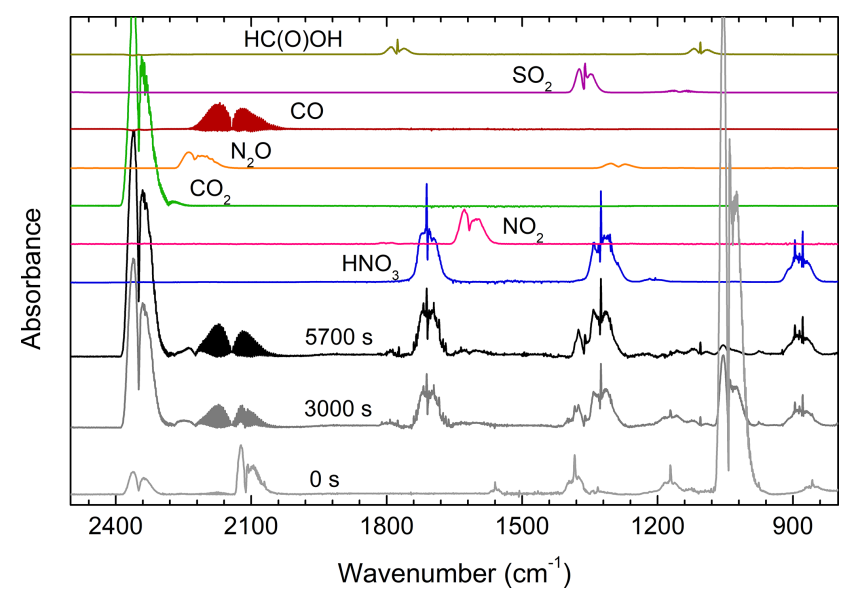

Figure 4. Infrared spectrum acquired prior to $(0 \mathrm{~s})$ and after $(3000$ and $5700 \mathrm{~s}$ ) photolysis of a mixture of MSAM, $\mathrm{O}_{3}, \mathrm{H}_{2}$, and air. During irradiation, $\mathrm{OH}$ concentrations were $\approx 3 \times 10^{9}$ molec. $\mathrm{cm}^{-3}$. $\mathrm{H}_{2} \mathrm{O}$-absorption features have been subtracted from the spectra. Reference spectrum of $\mathrm{HNO}_{3}, \mathrm{NO}_{2}, \mathrm{CO}_{2}, \mathrm{~N}_{2} \mathrm{O}, \mathrm{CO}, \mathrm{SO}_{2}$, and $\mathrm{HC}(\mathrm{O}) \mathrm{OH}$ recorded under the same experimental conditions (700 Torr and $298 \mathrm{~K}$ ) are also shown.

and MSAM by switching the Hg lamps on, IR spectra (700$4000 \mathrm{~cm}^{-1}$ ) were taken at $300 \mathrm{~s}$ intervals.

Figure 4 shows the initial spectrum of the gas mixture with $\mathrm{O}_{3}$ bands at $903-1068$ and $2064-2134 \mathrm{~cm}^{-1}$ (A), with the spectrum after $3000 \mathrm{~s}$ (B) showing depletion of MSAM and formation of products and the final products after the disappearance of the Q-branches (at 1172 and $1385 \mathrm{~cm}^{-1}$ ) of MSAM after $5700 \mathrm{~s}$ (C). The IR-absorption bands of water vapour have been subtracted from the spectra. Both $\mathrm{CO}_{2}$ $\left(2387-2300 \mathrm{~cm}^{-1}\right)$ and CO $\left(2226-2050 \mathrm{~cm}^{-1}\right)$ are observed from the photolysis of compounds adsorbed on the walls and surfaces of the cell, and they do not result solely from MSAM degradation.

Figure 4 also displays reference spectra (measured at the same temperature and pressure) of the compounds we identified as reaction products. Other than $\mathrm{CO}_{2}$ and $\mathrm{CO}$, nitric acid $\left(\mathrm{HNO}_{3}\right)$ and sulfur dioxide $\left(\mathrm{SO}_{2}\right)$ are easily identified, with weak features from $\mathrm{N}_{2} \mathrm{O}, \mathrm{NO}_{2}$, and formic acid $(\mathrm{HC}(\mathrm{O}) \mathrm{OH})$ also apparent. The absorption of each product was converted to a concentration using calibration curves that were obtained at the same pressure and temperature (see Fig. S2).

Figure 5 plots the concentration of $\mathrm{SO}_{2}$ (the only sulfurcontaining product observed), the sum of $\mathrm{HNO}_{3}+2 \mathrm{~N}_{2} \mathrm{O}$ (the total reactive nitrogen observed as product), and the sum of $\mathrm{CO}_{2}+\mathrm{CO}+\mathrm{HC}(\mathrm{O}) \mathrm{OH}$ (total carbon-containing products observed) versus the fractional depletion of MSAM. The concentrations after $6000 \mathrm{~s}$ (when $\sim 90 \%$ of the MSAM had reacted) were $\left[\mathrm{SO}_{2}\right]=5.74 \times 10^{13},\left[\mathrm{HNO}_{3}\right]=3.15 \times 10^{13}$, $\left[\mathrm{N}_{2} \mathrm{O}\right]=4.17 \times 10^{12},\left[\mathrm{CO}_{2}\right]=4.13 \times 10^{13},[\mathrm{CO}]=1.65 \times$ $10^{13}$, and $[\mathrm{HC}(\mathrm{O}) \mathrm{OH}]=1.77 \times 10^{12}$ molec. $\mathrm{cm}^{-3}$. MSAM contains one atom each of sulfur, nitrogen, and carbon. If

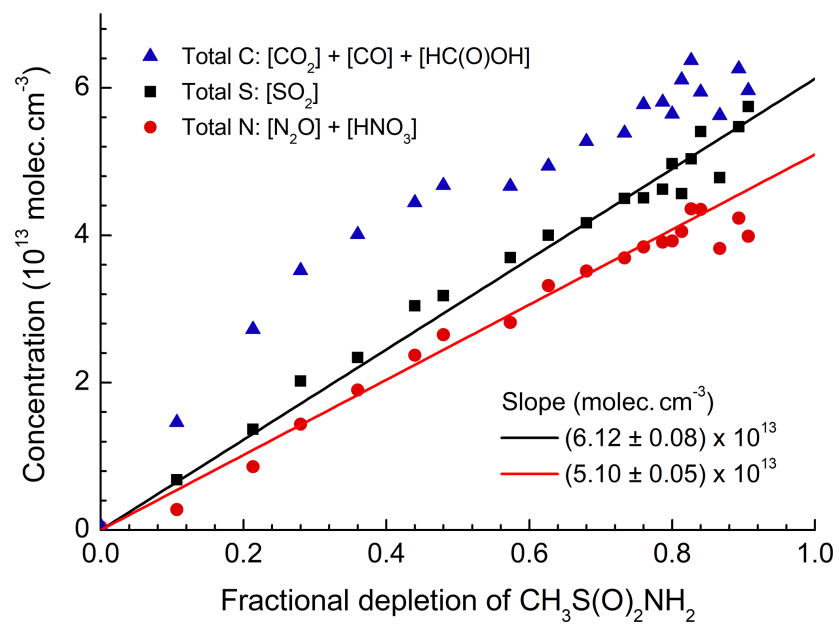

Figure 5. Summed concentration of carbon-containing products $\left(\mathrm{CO}_{2}, \mathrm{CO}\right.$, and $\left.\mathrm{HC}(\mathrm{O}) \mathrm{OH}\right)$, sulfur-containing products $\left(\mathrm{SO}_{2}\right)$, and nitrogen-containing products $\left(\mathrm{N}_{2} \mathrm{O}\right.$ and $\left.\mathrm{HNO}_{3}\right)$ plotted versus the relative depletion of MSAM. The slope gives the initial concentration of MSAM assuming stoichiometric conversion to the products listed.

$\mathrm{SO}_{2}$, reactive nitrogen, and carbon are conserved, we can derive initial concentrations of MSAM (from the slope) of $6.12 \pm 0.08 \times 10^{12}$ molec. $\mathrm{cm}^{-3}$ (based on the sulfur balance), $5.10 \pm 0.05 \times 10^{12}$ molec. $\mathrm{cm}^{-3}$ (based on the nitrogen balance), and $7.4 \pm 0.2 \times 10^{12}$ molec. $\mathrm{cm}^{-3}$ (based on the carbon balance at the maximum fractional depletion of MSAM). As already mentioned, total carbon is very likely to be overestimated due to its formation and desorption at/from the walls of the chamber. As the main nitrogen product is $\mathrm{HNO}_{3}$, which has a large affinity for surfaces and which is likely to be lost to the walls, we also expect that use of reactive nitrogen will result in an underestimation of the initial MSAM concentration. For these reasons we believe that the best method to estimate the initial concentration of MSAM is via the formation of $\mathrm{SO}_{2}$. Figure $\mathrm{S} 3$ illustrates the strict proportionality between the relative change of the $\mathrm{SO}_{2}$ concentration and the MSAM absorption feature at $1384 \mathrm{~cm}^{-1}$ in four different experiments. From these four experiments we derive absorption cross sections for MSAM at this wavenumber of $(4.06 \pm 0.17) \times 10^{-19} \mathrm{~cm}^{2}$ molec. ${ }^{-1}$. This value was used to scale the spectrum of MSAM (Fig. 1) and was used to calculate initial concentrations in all other experiments. Figure 6a presents a plot of $\Delta$ [product] vs. $-\Delta$ [MSAM] from one experiment. Apart from $\mathrm{CO}$, we observe a roughly linear relationship for all products. Time-dependent yields of each product are displayed in Fig. 6b. Whereas the yields of $\mathrm{SO}_{2}$, $\mathrm{CO}_{2}, \mathrm{~N}_{2} \mathrm{O}$, and $\mathrm{HC}(\mathrm{O}) \mathrm{OH}$ are within experimental scatter roughly constant, that of $\mathrm{HNO}_{3}$ (black line) reaches a constant value only after $800 \mathrm{~s}$, indicating that it is not formed directly, but in a secondary reaction. In contrast, the CO yield is initially slightly larger than unity (indicative of extra sources from the chamber walls) and then decreases with 

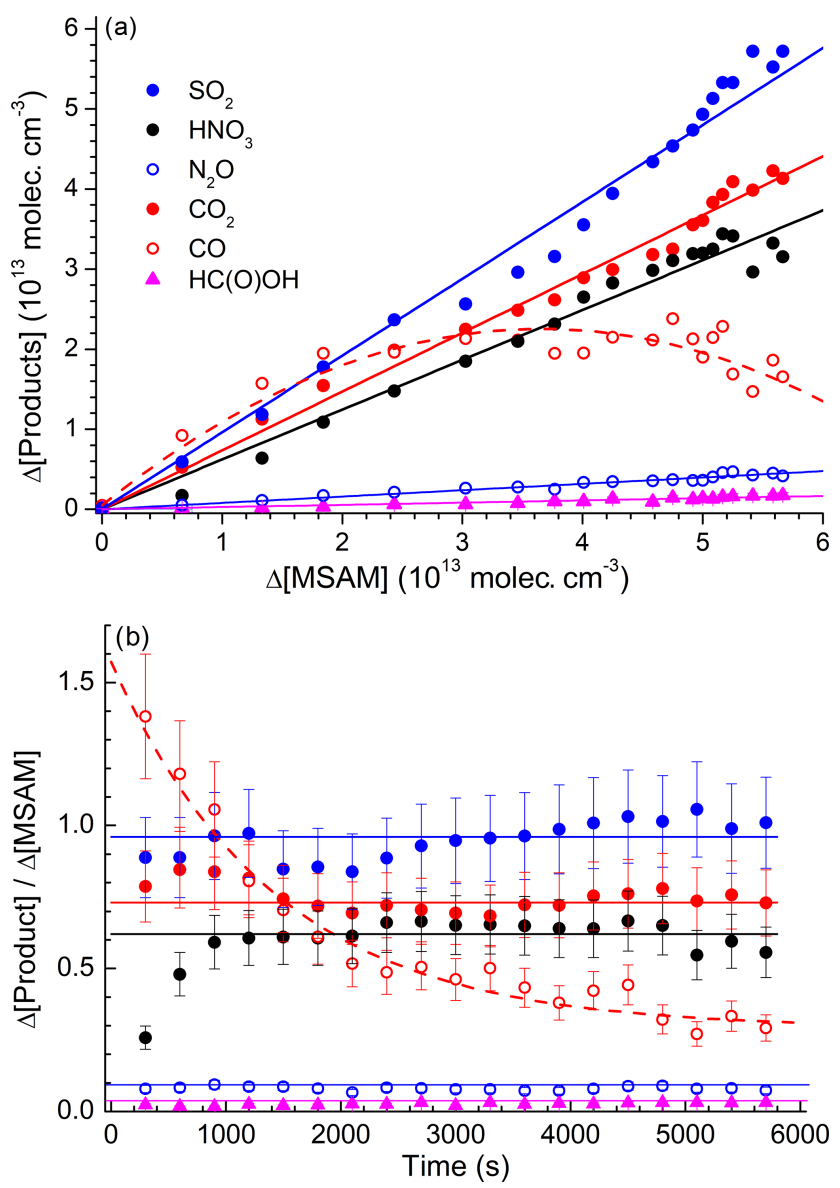

Figure 6. (a) Formation of products versus depletion of MSAM. The slopes of the linear fits are the yields of $\mathrm{SO}_{2}, \mathrm{HNO}_{3}, \mathrm{CO}_{2}$, $\mathrm{N}_{2} \mathrm{O}$, and $\mathrm{HC}(\mathrm{O}) \mathrm{OH}$ from this particular experiment. The polynomial fit to the $\mathrm{CO}$ data (red dash line) is added to guide the eye. (b) Time dependence of the product yields from the same experiment. The solid, horizontal lines represent the average yield. Error bars are total estimated uncertainty $(2 \sigma)$ including uncertainty in cross sections of products and MSAM.

time as it is removed (via reaction with $\mathrm{OH}$ ) to form $\mathrm{CO}_{2}$. The molar yields (after $6000 \mathrm{~s}$ of photolysis when MSAM has depleted to $\sim 20 \%$ of its original concentration) of the products obtained at $298 \mathrm{~K}$ and 700 Torr of synthetic air are $\Phi\left(\mathrm{SO}_{2}\right)=0.96 \pm 0.15, \Phi\left(\mathrm{HNO}_{3}\right)=0.62 \pm 0.09, \Phi\left(\mathrm{N}_{2} \mathrm{O}\right)=$ $0.09 \pm 0.02, \Phi\left(\mathrm{CO}_{2}\right)=0.73 \pm 0.11$, and $\Phi(\mathrm{HC}(\mathrm{O}) \mathrm{OH})=$ $0.03 \pm 0.01$. The slight deviation of $\Phi\left(\mathrm{SO}_{2}\right)$ from unity stems from the fact that the quoted yield is at a fixed time, whereas the initial MSAM concentration was derived using all the $\mathrm{SO}_{2}$ data in this experiment as described above. As $\mathrm{N}_{2} \mathrm{O}$ contains two $\mathrm{N}$ atoms, the nitrogen balance is thus $0.80 \pm 0.13$. It is likely that some $\mathrm{HNO}_{3}$ is lost to reactor surfaces, explaining the deviation from unity. Note that if we had used the nitrogen balance to derive the MSAM IR cross sections, the $\mathrm{SO}_{2}$ yield would have exceeded unity.

\subsection{Reaction mechanism}

The time-dependent formation of $\mathrm{HNO}_{3}, \mathrm{SO}_{2}, \mathrm{~N}_{2} \mathrm{O}$, and $\mathrm{CO}$ provides important clues to the reaction mechanism. Addition to the $\mathrm{S}$ atom is not possible so that the initial step will be abstraction of hydrogen by the $\mathrm{OH}$ radical, either from the $-\mathrm{CH}_{3}$ group (Reaction $\mathrm{R} 8 \mathrm{a}$ ) or from the $-\mathrm{NH}_{2}$ group (Reaction R8b).

$$
\begin{aligned}
& \mathrm{CH}_{3} \mathrm{SO}_{2} \mathrm{NH}_{2}+\mathrm{OH} \rightarrow \mathrm{CH}_{2} \mathrm{SO}_{2} \mathrm{NH}_{2}+\mathrm{H}_{2} \mathrm{O} \\
& \mathrm{CH}_{3} \mathrm{SO}_{2} \mathrm{NH}_{2}+\mathrm{OH} \rightarrow \mathrm{CH}_{3} \mathrm{SO}_{2} \mathrm{NH}+\mathrm{H}_{2} \mathrm{O}
\end{aligned}
$$

Based on results of previous studies of the reactions of $\mathrm{OH}$ with trace gases containing both $\mathrm{CH}_{3}$ and $-\mathrm{NH}_{2}$ entities (e.g. $\mathrm{CH}_{3} \mathrm{NH}_{2}$ or $\mathrm{CH}_{3} \mathrm{C}(\mathrm{O}) \mathrm{NH}_{2}$ ), we expect abstraction at the $-\mathrm{CH}_{3}$ group (Reaction R8a) to dominate (Onel et al., 2014; Borduas et al., 2015; Butkovskaya and Setser, 2016). $\mathrm{H}$ abstraction at the methyl group is also consistent with a rate coefficient for Reaction (R4) that is very similar to that for $\mathrm{OH}+$ acetone.

\subsubsection{Abstraction from the $-\mathrm{CH}_{3}$ group}

In Sect. 3.4.1 we focus on the fate of the peroxy radical, $\mathrm{OOCH}_{2} \mathrm{SO}_{2} \mathrm{NH}_{2}$, formed by reaction of initially formed $\mathrm{CH}_{2} \mathrm{SO}_{2} \mathrm{NH}_{2}$ with $\mathrm{O}_{2}$ (Reaction R9). The most important reactions of organic peroxy radicals are self-reactions (Reaction R10) or reactions with $\mathrm{NO}$ (Reaction R11), $\mathrm{NO}_{2}$ (Reaction R12), or $\mathrm{HO}_{2}$ (Reaction R13).

$$
\begin{aligned}
& \mathrm{CH}_{2} \mathrm{SO}_{2} \mathrm{NH}_{2}+\mathrm{O}_{2} \rightarrow \mathrm{OOCH}_{2} \mathrm{SO}_{2} \mathrm{NH}_{2} \\
& 2 \mathrm{OOCH}_{2} \mathrm{SO}_{2} \mathrm{NH}_{2} \rightarrow \mathrm{OCH}_{2} \mathrm{SO}_{2} \mathrm{NH}_{2}+\mathrm{O}_{2} \\
& \mathrm{OOCH}_{2} \mathrm{SO}_{2} \mathrm{NH}_{2}+\mathrm{NO} \rightarrow \mathrm{OCH}_{2} \mathrm{SO}_{2} \mathrm{NH}_{2}+\mathrm{NO}_{2} \\
& \mathrm{OOCH}_{2} \mathrm{SO}_{2} \mathrm{NH}_{2}+\mathrm{NO}_{2} \rightarrow \mathrm{O}_{2} \mathrm{NOOCH}_{2} \mathrm{SO}_{2} \mathrm{NH}_{2} \\
& \mathrm{OOCH}_{2} \mathrm{SO}_{2} \mathrm{NH}_{2}+\mathrm{HO}_{2} \rightarrow \mathrm{HOOCH}_{2} \mathrm{SO}_{2} \mathrm{NH}_{2}+\mathrm{O}_{2}
\end{aligned}
$$

Peroxy nitrates such as the one formed in Reaction (R12) are thermally unstable with respect to dissociation back to reactants at room temperature, and, given the very low concentrations of $\mathrm{NO}_{2}$ in our system, Reaction (R12) will not play a significant role in this study.

The oxy-radical $\mathrm{OCH}_{2} \mathrm{SO}_{2} \mathrm{NH}_{2}$ formed in Reactions (R10) and (R11) will react with $\mathrm{O}_{2}$ to produce an aldehyde (Reaction R14). Alternatively, it could undergo $\mathrm{C}-\mathrm{S}$ bond cleavage (Reaction R15) to form formaldehyde $\left(\mathrm{CH}_{2} \mathrm{O}\right)$ and the $\mathrm{SO}_{2} \mathrm{NH}_{2}$ radical.

$$
\begin{aligned}
& \mathrm{OCH}_{2} \mathrm{SO}_{2} \mathrm{NH}_{2}+\mathrm{O}_{2} \rightarrow \mathrm{HC}(\mathrm{O}) \mathrm{SO}_{2} \mathrm{NH}_{2}+\mathrm{HO}_{2} \\
& \mathrm{OCH}_{2} \mathrm{SO}_{2} \mathrm{NH}_{2} \rightarrow \mathrm{CH}_{2} \mathrm{O}+\mathrm{SO}_{2} \mathrm{NH}_{2}
\end{aligned}
$$

The fate of $\mathrm{HC}(\mathrm{O}) \mathrm{SO}_{2} \mathrm{NH}_{2}$ will be reaction with $\mathrm{OH}$ to form $\mathrm{C}(\mathrm{O}) \mathrm{SO}_{2} \mathrm{NH}_{2}$ (Reaction R16), which may dissociate to form $\mathrm{CO}+\mathrm{SO}_{2} \mathrm{NH}_{2}$ (Reaction $\left.\mathrm{R} 17\right)$. The rate coefficient for Reaction (R16) is expected to be $\approx 10^{-11} \mathrm{~cm}^{3}$ molec. $^{-1} \mathrm{~s}^{-1}$ 
as for many similar reactions of $\mathrm{OH}$ with aldehydes (e.g. $\mathrm{CH}_{3} \mathrm{CHO}$ ).

$$
\mathrm{HC}(\mathrm{O}) \mathrm{SO}_{2} \mathrm{NH}_{2}+\mathrm{OH} \rightarrow \mathrm{C}(\mathrm{O}) \mathrm{SO}_{2} \mathrm{NH}_{2}+\mathrm{H}_{2} \mathrm{O}
$$

$\mathrm{C}(\mathrm{O}) \mathrm{SO}_{2} \mathrm{NH}_{2}$ may either decompose to $\mathrm{SO}_{2} \mathrm{NH}_{2}$ and $\mathrm{CO}$ (Reaction R17) or react with $\mathrm{O}_{2}$ to form an $\alpha$-carbonyl peroxy radical (Reaction $\mathrm{R} 18$ ).

$$
\begin{aligned}
& \mathrm{C}(\mathrm{O}) \mathrm{SO}_{2} \mathrm{NH}_{2} \rightarrow \mathrm{SO}_{2} \mathrm{NH}_{2}+\mathrm{CO} \\
& \mathrm{C}(\mathrm{O}) \mathrm{SO}_{2} \mathrm{NH}_{2}+\mathrm{O}_{2}+\mathrm{M} \rightarrow \mathrm{O}_{2} \mathrm{C}(\mathrm{O}) \mathrm{SO}_{2} \mathrm{NH}_{2}+\mathrm{M}
\end{aligned}
$$

The fate of $\mathrm{O}_{2} \mathrm{C}(\mathrm{O}) \mathrm{SO}_{2} \mathrm{NH}_{2}$ is likely to be dominated by reaction with $\mathrm{HO}_{2}$, which, by analogy to $\mathrm{CH}_{3} \mathrm{C}(\mathrm{O}) \mathrm{O}_{2}$ (another $\alpha$-carbonyl peroxy radical), is expected to lead to the reformation of OH (Dillon and Crowley, 2008; Groß et al., 2014).

$$
\begin{aligned}
& \mathrm{O}_{2} \mathrm{C}(\mathrm{O}) \mathrm{SO}_{2} \mathrm{NH}_{2}+\mathrm{HO}_{2} \rightarrow \\
& \mathrm{OH}+\mathrm{O}_{2}+\mathrm{CO}_{2}+\mathrm{SO}_{2} \mathrm{NH}_{2}
\end{aligned}
$$

In both scenarios, $\mathrm{SO}_{2} \mathrm{NH}_{2}$ is the sulfur-containing product, whereas formation of the peroxy radical in Reaction (R18) will result in early $\mathrm{CO}_{2}$ formation and $\mathrm{OH}$ recycling.

Formaldehyde formed in Reaction (R15) will react with $\mathrm{OH}$ to form $\mathrm{CO}$ and subsequently $\mathrm{CO}_{2}$.

$$
\begin{aligned}
& \mathrm{CH}_{2} \mathrm{O}+\mathrm{OH} \rightarrow \mathrm{HCO}+\mathrm{H}_{2} \mathrm{O} \\
& \mathrm{HCO}+\mathrm{O}_{2} \rightarrow \mathrm{HO}_{2}+\mathrm{CO} \\
& \mathrm{CO}+\mathrm{OH}\left(+\mathrm{O}_{2}\right) \rightarrow \mathrm{CO}_{2}+\mathrm{HO}_{2}
\end{aligned}
$$

But it may also react with $\mathrm{HO}_{2}$ to form formic acid.

$$
\begin{aligned}
& \mathrm{CH}_{2} \mathrm{O}+\mathrm{HO}_{2}+\mathrm{M} \rightarrow \mathrm{HOCH}_{2} \mathrm{OO}+\mathrm{M} \\
& 2 \mathrm{HOCH}_{2} \mathrm{OO} \rightarrow \mathrm{HOCH}_{2} \mathrm{O}+\mathrm{O}_{2} \\
& \mathrm{HOCH}_{2} \mathrm{O}+\mathrm{O}_{2} \rightarrow \mathrm{HC}(\mathrm{O}) \mathrm{OH}+\mathrm{HO}_{2}
\end{aligned}
$$

The above reactions explain, at least qualitatively, the observed formation of $\mathrm{CO}, \mathrm{CO}_{2}$, and $\mathrm{HC}(\mathrm{O}) \mathrm{OH}$. Note that the room temperature rate coefficient for reaction of $\mathrm{OH}$ with HCHO is large $\left(8.5 \times 10^{-12} \mathrm{~cm}^{3}\right.$ molec. ${ }^{-1} \mathrm{~s}^{-1}$; Atkinson et al., 2006) compared to that for reaction with $\mathrm{CO}$ $\left(2.2 \times 10^{-13} \mathrm{~cm}^{3}\right.$ molec. $^{-1} \mathrm{~s}^{-1}$; Atkinson et al., 2006), which explains why $\mathrm{CO}$ was observed as an intermediate product at high concentrations whereas $\mathrm{HCHO}$ was not.

The likely fate of the $\mathrm{SO}_{2} \mathrm{NH}_{2}$ radical formed in Reaction (R15) is either reaction with $\mathrm{O}_{2}$ to generate $\mathrm{SO}_{2} \mathrm{NH}$ or dissociation by $\mathrm{S}-\mathrm{N}$ bond scission to produce $\mathrm{SO}_{2}$ and the $\mathrm{NH}_{2}$ radical.

$$
\begin{aligned}
& \mathrm{SO}_{2} \mathrm{NH}_{2}+\mathrm{O}_{2} \rightarrow \mathrm{SO}_{2} \mathrm{NH}+\mathrm{HO}_{2} \\
& \mathrm{SO}_{2} \mathrm{NH}_{2} \rightarrow \mathrm{SO}_{2}+\mathrm{NH}_{2}
\end{aligned}
$$

We did not observe features in the IR spectrum that could be assigned to $\mathrm{SO}_{2} \mathrm{NH}$ based on the spectrum reported by Deng et al. (2016), and we propose that Reaction (R27) is the source of $\mathrm{SO}_{2}$ as a major reaction product. By analogy with the thermal decomposition of the similar $\mathrm{CH}_{3} \mathrm{SO}_{2}$ radical, which dissociates to $\mathrm{CH}_{3}$ and $\mathrm{SO}_{2}$ on a millisecond timescale (Ray et al., 1996), we expect $\mathrm{SO}_{2} \mathrm{NH}_{2}$ to decompose stoichiometrically to $\mathrm{SO}_{2}$ and $\mathrm{NH}_{2}$ on the timescale of our experiments. The $\mathrm{NH}_{2}$ radical is known to react with $\mathrm{O}_{3}$, $\mathrm{HO}_{2}$, and $\mathrm{NO}_{2}$ (IUPAC, 2019).

$\mathrm{NH}_{2}+\mathrm{O}_{3} \rightarrow \mathrm{NH}_{2} \mathrm{O}+\mathrm{O}_{2}$

$\mathrm{NH}_{2}+\mathrm{HO}_{2} \rightarrow \mathrm{NH}_{2} \mathrm{O}+\mathrm{OH}$

$\mathrm{NH}_{2}+\mathrm{HO}_{2} \rightarrow \mathrm{HNO}+\mathrm{H}_{2} \mathrm{O}$

$\mathrm{NH}_{2}+\mathrm{NO}_{2} \rightarrow \mathrm{N}_{2} \mathrm{O}+\mathrm{H}_{2} \mathrm{O}$

$\mathrm{NH}_{2} \mathrm{O}$ rearranges within $\sim 1$ ms to $\mathrm{NHOH}$ (Kohlmann and Poppe, 1999), which then reacts with $\mathrm{OH}$ or $\mathrm{O}_{2}$ to generate HNO.

$$
\begin{aligned}
& \mathrm{NHOH}+\mathrm{OH} \rightarrow \mathrm{HNO}+\mathrm{H}_{2} \mathrm{O} \\
& \mathrm{NHOH}+\mathrm{O}_{2} \rightarrow \mathrm{HNO}+\mathrm{HO}_{2}
\end{aligned}
$$

The fate of $\mathrm{HNO}$ is the reaction with $\mathrm{OH}$ or $\mathrm{O}_{2}$ to generate NO (Reactions R33 and R34).

$\mathrm{HNO}+\mathrm{O}_{2} \rightarrow \mathrm{NO}+\mathrm{HO}_{2}$
$\mathrm{HNO}+\mathrm{OH} \rightarrow \mathrm{NO}+\mathrm{H}_{2} \mathrm{O}$

High concentrations of $\mathrm{O}_{3}\left(\approx 10^{14}\right.$ molec. $\left.\mathrm{cm}^{-3}\right)$ and $\mathrm{HO}_{2}$ $\left(\approx 10^{11}\right.$ molec. $\left.\mathrm{cm}^{-3}\right)$ in our system ensure that NO is converted to $\mathrm{NO}_{2}$ in less than $1 \mathrm{~s}$, explaining the non-observation of the IR absorption features of NO.

$\mathrm{NO}+\mathrm{O}_{3} \rightarrow \mathrm{NO}_{2}+\mathrm{O}_{2}$
$\mathrm{NO}+\mathrm{HO}_{2} \rightarrow \mathrm{NO}_{2}+\mathrm{OH}$

Finally, $\mathrm{NO}_{2}$ in this system will react with $\mathrm{OH}$ to form the main reactive nitrogen compound we observed, $\mathrm{HNO}_{3}$.

$\mathrm{NO}_{2}+\mathrm{OH}+\mathrm{M} \rightarrow \mathrm{HNO}_{3}+\mathrm{M}$

Thus far we have not considered the reaction of the peroxy radical $\mathrm{OOCH}_{2} \mathrm{SO}_{2} \mathrm{NH}_{2}$ with $\mathrm{HO}_{2}$ (Reaction R13), which is expected to result in the formation of a peroxide, $\mathrm{HOOCH}_{2} \mathrm{SO}_{2} \mathrm{NH}_{2}$. The most likely fate of $\mathrm{HOOCH}_{2} \mathrm{SO}_{2} \mathrm{NH}_{2}$ is reaction with $\mathrm{OH}$ for which (via comparison with $\mathrm{CH}_{3} \mathrm{OOH}$ ) a rate coefficient close to $1-5 \times$ $10^{-12} \mathrm{~cm}^{3}$ molec. ${ }^{-1} \mathrm{~s}^{-1}$ may be expected with $\mathrm{H}$ abstraction from both the peroxide group (Reaction R38) and the adjacent carbon (Reaction R39).

$$
\begin{aligned}
& \mathrm{HOOCH}_{2} \mathrm{SO}_{2} \mathrm{NH}_{2}+\mathrm{OH} \rightarrow \mathrm{OOCH}_{2} \mathrm{SO}_{2} \mathrm{NH}_{2}+\mathrm{H}_{2} \mathrm{O} \\
& \mathrm{HOOCH}_{2} \mathrm{SO}_{2} \mathrm{NH}_{2}+\mathrm{OH} \rightarrow \mathrm{HOOCHSO}_{2} \mathrm{NH}_{2}+\mathrm{H}_{2} \mathrm{O}
\end{aligned}
$$

Reaction (R38) regenerates the peroxy radical, whereas the $\mathrm{HOOCHSO}_{2} \mathrm{NH}_{2}$ radical may decompose (Reaction R40) 
to form formic acid $\mathrm{HC}(\mathrm{O}) \mathrm{OH}$ or decomposes via Reaction (R41) to form the same aldehyde that is generated in Reaction (R14), whilst regenerating $\mathrm{OH}$.

$$
\begin{aligned}
& \mathrm{HOOCHSO}_{2} \mathrm{NH}_{2} \rightarrow \mathrm{HC}(\mathrm{O}) \mathrm{OH}+\mathrm{SO}_{2} \mathrm{NH}_{2} \\
& \mathrm{HOOCHSO}_{2} \mathrm{NH}_{2} \rightarrow \mathrm{OH}+\mathrm{HC}(\mathrm{O}) \mathrm{SO}_{2} \mathrm{NH}_{2}
\end{aligned}
$$

The final products are thus the same as those resulting from the self-reaction of the peroxy radical. The path from MSAM to the observed end products including the reactive intermediates that were not observed is illustrated in Fig. 7.

\subsubsection{Abstraction from the $-\mathrm{NH}_{2}$ group}

In analogy to the reaction between $\mathrm{CH}_{3} \mathrm{C}(\mathrm{O}) \mathrm{NH}_{2}$ and $\mathrm{OH}$ (Barnes et al., 2010), $\mathrm{H}$ abstraction from the $-\mathrm{NH}_{2}$ group is expected to result in decomposition of the initially formed $\mathrm{CH}_{3} \mathrm{SO}_{2} \mathrm{NH}$ radical via $\mathrm{C}-\mathrm{S}$ bond fission.

$$
\mathrm{CH}_{3} \mathrm{SO}_{2} \mathrm{NH} \rightarrow \mathrm{CH}_{3}+\mathrm{SO}_{2} \mathrm{NH}
$$

The methyl radical would react with $\mathrm{O}_{2}$ to form the methylperoxy radical and in subsequent reactions (via $\mathrm{CH}_{3} \mathrm{O}$ ) would result in $\mathrm{CH}_{2} \mathrm{O}$ formation. As discussed above, $\mathrm{CH}_{2} \mathrm{O}$ will be efficiently oxidized to $\mathrm{CO}$ and $\mathrm{CO}_{2}$ in this system. However, the characteristic IR-absorption bands (Deng et al., 2016) of the $\mathrm{SO}_{2} \mathrm{NH}$ product were not observed in our experiments, and calculations at the G4MP2 level of theory indicate that Reaction (R42) is endothermic (by $137 \mathrm{~kJ} \mathrm{~mol}^{-1}$ ). We conclude that $\mathrm{H}$ abstraction from the $-\mathrm{NH}_{2}$ group is a minor channel.

\subsection{Kinetic simulation}

The proposed reaction mechanism (considering initial reaction by $\mathrm{H}$ abstraction from the $-\mathrm{CH}_{3}$ group only) was tested by kinetic simulation using the KINTECUS program package (Ianni, 2015). The reactions used in the chemical scheme and the associated rate coefficients are presented in Table S2. Where experimental rate coefficients were not available, we used rate parameters from similar reactions, and we rationalize these choices in the text associated with Table S2.

Figure 8 shows the variation in the concentrations of the reagent, intermediates, and products observed as a function of time in an experiment conducted at $298 \mathrm{~K}$ and 700 Torr of synthetic air. The error bars consider uncertainty associated with the absorption cross sections (5\%-12\%) and uncertainty in deriving the areas of the absorption band areas (less than $3 \%$ in all cases). For MSAM, an uncertainty of $\approx 25 \%$ is expected, based on the indirect method of calibration (see Sect. 3.2). The simulation results are depicted as solid lines.

The good agreement with the $\mathrm{N}_{2} \mathrm{O}$ (formed from $\mathrm{NH}_{2}$ in Reaction R28) and $\mathrm{HNO}_{3}$ experimental data suggests that the fate of $\mathrm{NH}_{2}$ (the only source of reactive nitrogen in this system) is accurately described in the model. Note that the wall loss rate of $\mathrm{HNO}_{3}\left(1 \times 10^{-5} \mathrm{~s}^{-1}\right)$ in the simulation was adjusted to match the $\mathrm{HNO}_{3}$ profile. The simulated amount of $\mathrm{HNO}_{3}$ lost to the wall at the end of the experiment was $\approx 14 \%$ of that formed, which helps to explain the non-unity yield of gas-phase nitrogen compounds. The simulations indicate that the maximum concentrations of $\mathrm{NO}$ $\left(7 \times 10^{9}\right.$ molec. $\left.\mathrm{cm}^{-3}\right)$ and $\mathrm{NO}_{2}\left(\sim 10^{12}\right.$ molec. $\left.\mathrm{cm}^{-3}\right)$ are below the detection limit of the instrument and explain why they were not observed. The strongest absorption features of $\mathrm{HCHO}\left(1700-1800 \mathrm{~cm}^{-1}\right)$ overlap with those of $\mathrm{H}_{2} \mathrm{O}$ and $\mathrm{HNO}_{3}$ so that the predicted concentrations of $\mathrm{HCHO}$ $\left(\sim 10^{12}\right.$ molec. $\left.\mathrm{cm}^{-3}\right)$ are also below the detection limit.

The grey line in Fig. 8 represents the sum of $\mathrm{SO}_{2}+\mathrm{SO}_{3}+$ $\mathrm{H}_{2} \mathrm{SO}_{4}$, i.e. all model trace gases containing sulfur, which, in the absence of IR absorption features of $\mathrm{SO}_{3}$ or $\mathrm{H}_{2} \mathrm{SO}_{4}$, we equate to $\mathrm{SO}_{2}$. We now draw attention to the fact that $\mathrm{SO}_{2}$ (the yield of which is constant with time; see Fig. 6) is only well simulated if we neglect its removal by $\mathrm{OH}$ (Reaction R43).

$\mathrm{OH}+\mathrm{SO}_{2}+\mathrm{M} \rightarrow \mathrm{HOSO}_{2}+\mathrm{M}$

Otherwise, using the preferred rate constant (IUPAC, 2019) at 700 Torr and $298 \mathrm{~K}$ of $9.0 \times 10^{-13} \mathrm{~cm}^{3}$ molec. ${ }^{-1} \mathrm{~s}^{-1}$ we find that the simulated $\mathrm{SO}_{2}$ concentration is significantly reduced and its yield is time dependent. At 1 bar of air, collisionally stabilized $\mathrm{HOSO}_{2}$ is converted within $1 \mu$ s to $\mathrm{HO}_{2}$ and $\mathrm{SO}_{3}$. In the atmosphere, $\mathrm{SO}_{3}$ reacts with $\mathrm{H}_{2} \mathrm{O}$ to form $\mathrm{H}_{2} \mathrm{SO}_{4}$ (Reaction R45). The conversion of $\mathrm{SO}_{3}$ to $\mathrm{H}_{2} \mathrm{SO}_{4}$ may be suppressed under our "dry" conditions.

$\mathrm{HOSO}_{2}+\mathrm{O}_{2} \rightarrow \mathrm{HO}_{2}+\mathrm{SO}_{3}$
$\mathrm{SO}_{3}+\left(\mathrm{H}_{2} \mathrm{O}\right)_{n} \rightarrow \mathrm{H}_{2} \mathrm{SO}_{4}+\left(\mathrm{H}_{2} \mathrm{O}\right)_{n-1}$

$\mathrm{SO}_{2}$ should therefore not behave like a stable end product in our experiments but be converted to more oxidized forms. In order to confirm that $\mathrm{SO}_{2}$ is indeed stable in our experiments, we measured the relative rate of loss of $\mathrm{SO}_{2}$ and acetone under the same experimental conditions (Fig. S4). The apparent relative rate constant $k_{43} / k_{5}$ was 0.46 , which converts to an effective rate constant for $\mathrm{SO}_{2}$ loss of $8.2 \times 10^{-14} \mathrm{~cm}^{3}$ molec. ${ }^{-1} \mathrm{~s}^{-1}$. This is more than a factor of 10 lower than the preferred value, indicating that the net rate of the $\mathrm{OH}$-induced $\mathrm{SO}_{2}$ loss in our system is much lower than expected and not simply governed by the rate constant for the forward reaction to form $\mathrm{HOSO}_{2}$. The reformation of $\mathrm{SO}_{2}$ under our experimental conditions is the subject of ongoing experiments in this laboratory, which are beyond the scope of the present study. We note that the unexpected behaviour of $\mathrm{SO}_{2}$ does not significantly impact the conclusions drawn in this work.

The simulation also captures the $\mathrm{CO}$ profile well but fails to predict the early formation of $\mathrm{CO}_{2}$. The match between simulation and experiment could be improved to some extent for $\mathrm{CO}_{2}$ by amending the fate of the $\mathrm{C}(\mathrm{O}) \mathrm{SO}_{2} \mathrm{NH}_{2}$ radical as described above (Reactions $\mathrm{R} 17$ and R18) so that $\mathrm{CO}_{2}$ rather 


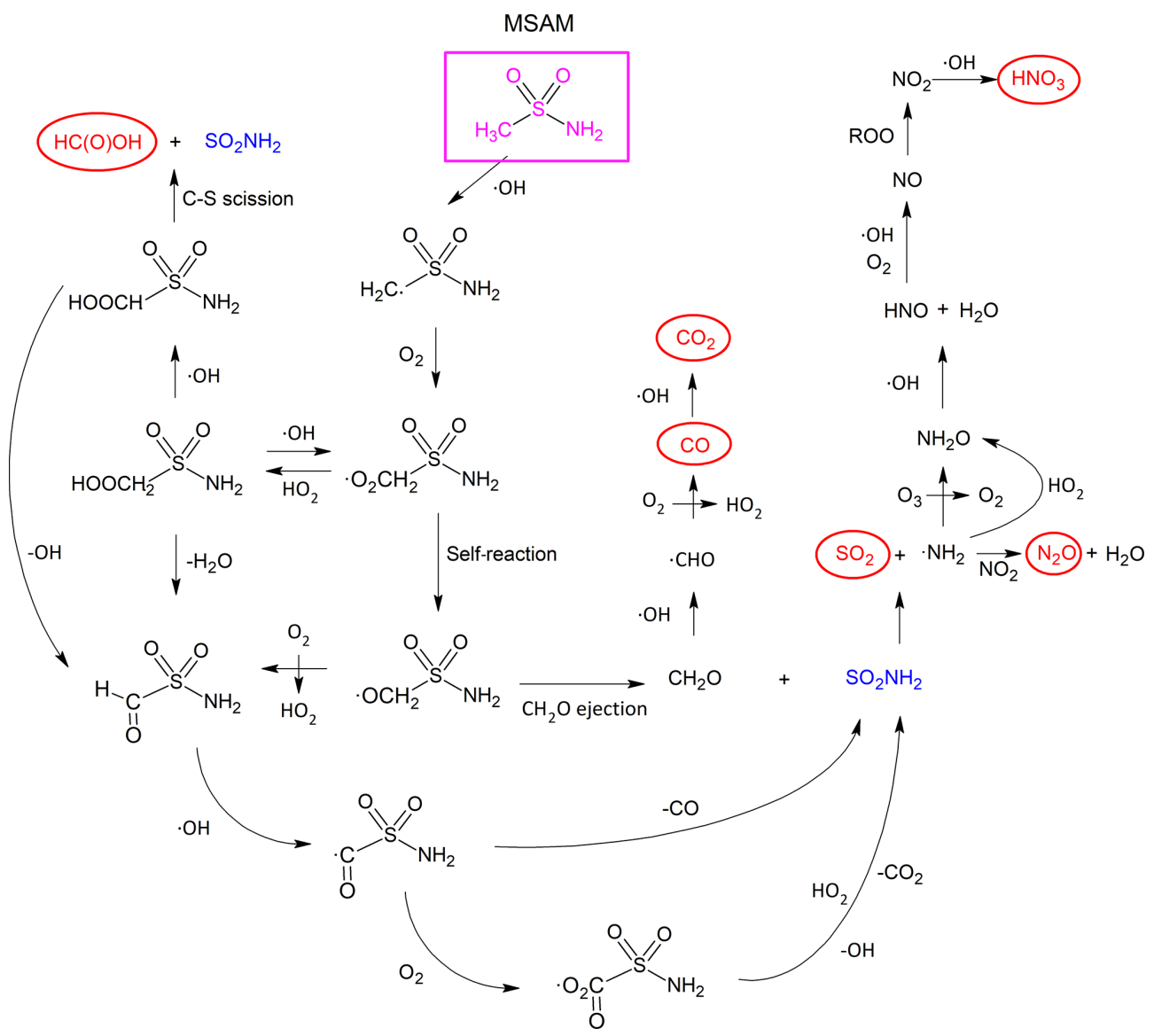

Figure 7. Mechanism for the formation of carbon-containing $\left(\mathrm{HC}(\mathrm{O}) \mathrm{OH}, \mathrm{CO}, \mathrm{CO}_{2}\right)$, nitrogen-containing $\left(\mathrm{HNO}_{3}\right.$ and $\left.\mathrm{N}_{2} \mathrm{O}\right)$, and sulfurcontaining $\left(\mathrm{SO}_{2}\right)$ end products (in red circles) observed in the $\mathrm{OH}$-initiated photo-oxidation of MSAM.

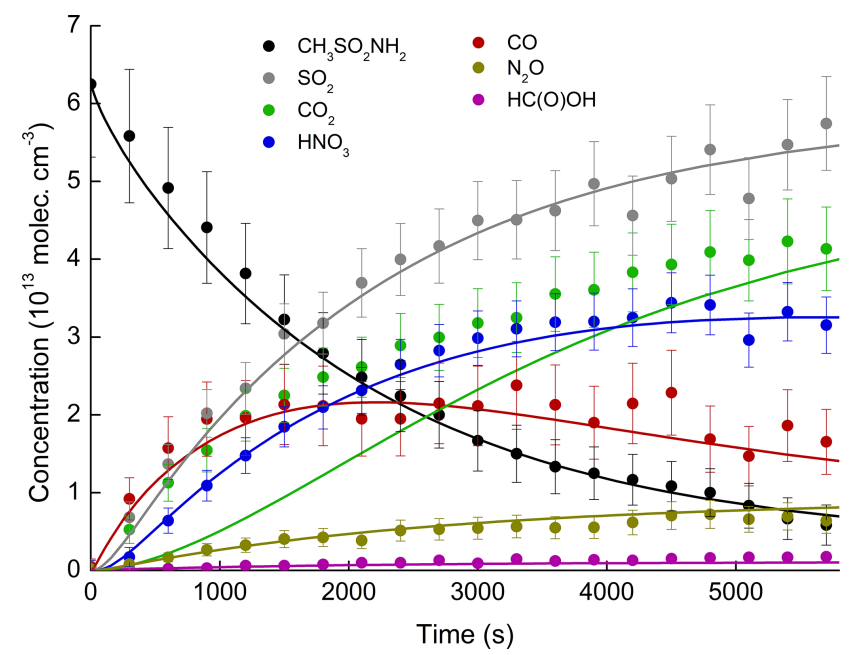

Figure 8. Concentration-time profiles of MSAM and reaction products formed in an experiment at $298 \mathrm{~K}$ and 700 Torr air. The error bars represent uncertainty in infrared cross sections. The uncertainty associated with the MSAM concentration is estimated to be $\approx 25 \%$. Solid lines are simulated profiles. than $\mathrm{CO}$ is formed. The results (Fig. S5) indicate that the improved simulation of $\mathrm{CO}_{2}$ is accompanied by complete loss of agreement with $\mathrm{CO}$ (which is no longer formed in measurable amounts) and poorer agreement with, for example, $\mathrm{SO}_{2}$ and $\mathrm{HNO}_{3}$. However, given that $\mathrm{CO}_{2}$ is generated from the cell walls during irradiation and cannot be used quantitatively (Sect. 3.5), the true fate of the $\mathrm{C}(\mathrm{O}) \mathrm{SO}_{2} \mathrm{NH}_{2}$ radical remains obscure.

\subsection{Atmospheric implications}

The rate coefficients for a number of tropospheric, organosulfur trace gases are listed in Table 3. The rate coefficient for the title reaction is significantly lower than those for $\mathrm{CH}_{3} \mathrm{SCH}_{3}\left(\mathrm{CH}_{3} \mathrm{SCH}_{3}\right)$ and $\mathrm{CH}_{3} \mathrm{~S}(\mathrm{O}) \mathrm{CH}_{3}$, (DMSO) for which reaction with $\mathrm{OH}$ is the major atmospheric loss process (lifetimes of hours), but it is comparable to $\mathrm{CH}_{3} \mathrm{~S}(\mathrm{O})_{2} \mathrm{CH}_{3}$, which also has two $\mathrm{S}=\mathrm{O}$ double bonds. However, as for most tropospheric trace gases, the lifetime of MSAM will be controlled by a number of processes including photolysis; reactions with the three major oxidants, $\mathrm{OH}, \mathrm{NO}_{3}$, and $\mathrm{O}_{3}$; and dry deposition $\left(k_{\mathrm{dd}}\right)$ and heterogeneous uptake to particles $\left(k_{\text {het }}\right)$, followed by wet deposition. 
Table 3. Lifetimes of atmospheric organosulfur trace gases with respect to reaction with $\mathrm{OH}$.

\begin{tabular}{lrrl}
\hline & $k(\mathrm{OH})^{\mathrm{a}}$ & Lifetime $^{\mathrm{b}}$ & Reference \\
\hline $\mathrm{CH}_{3} \mathrm{SO}_{2} \mathrm{NH}_{2}$ & $1.4 \times 10^{-13}$ & $80 \mathrm{~d}$ & This work \\
$\mathrm{CH}_{3} \mathrm{SO}_{2} \mathrm{CH}_{3}$ & $<3 \times 10^{-13}$ & $>40 \mathrm{~d}$ & Falbe-Hansen et al. (2000) \\
$\mathrm{CH}_{3} \mathrm{~S}(\mathrm{O}) \mathrm{CH}_{3}$ & $5.9 \times 10^{-11}$ & $5 \mathrm{~h}$ & Falbe-Hansen et al. (2000) \\
$\mathrm{CH}_{3} \mathrm{SO}_{2} \mathrm{H}$ & $9.0 \times 10^{-11}$ & $2.8 \mathrm{~h}$ & Burkholder et al. (2015) \\
$\mathrm{CH}_{3} \mathrm{SCH}_{3}$ & $2.2 \times 10^{-12}$ & $1.6 \mathrm{~d}$ & Atkinson et al. (2004) \\
\hline${ }^{\text {a }}$ Units of cm ${ }^{3}$ molec. $^{-1} \mathrm{~s}^{-1}$. ${ }^{\mathrm{b}}$ Assumes a diel average OH concentration of $1 \times 10^{6}$ molec. cm
\end{tabular}

The lack of $\mathrm{C}=\mathrm{C}$ double bonds in MSAM suggest that the reaction with $\mathrm{O}_{3}$ will be a negligible sink, which is confirmed by the low upper limit to the rate constant of $1 \times 10^{-19} \mathrm{~cm}^{3}$ molec. ${ }^{-1} \mathrm{~s}^{-1}$ described in Sect. 2.4. Whereas the reaction with $\mathrm{NO}_{3}$ represents an important loss mechanism for DMS, we do not expect this to be important for MSAM. $\mathrm{CH}_{3} \mathrm{SCH}_{3}$ reacts with $\mathrm{NO}_{3}$ (despite lack of a $\mathrm{C}=\mathrm{C}$ double bond) as the high electron density around the sulfur atom enables a pre-reaction complex to form prior to $\mathrm{H}$ abstraction. This mechanism is not available for MSAM because the electron density around the sulfur atom is reduced by the two oxygen atoms attached to it, which also provide steric hindrance.

Owing to its low vapour pressure, we were unable to measure the UV-absorption spectrum of MSAM, but we note that it was not photolysed at a measurable rate by the $254 \mathrm{~nm}$ radiation in our study. We conclude that photolysis in the troposphere, where actinic flux only at wavelengths above $\geq 320 \mathrm{~nm}$ is available, is a negligible sink of MSAM.

Therefore, the lifetime of MSAM can be approximated by

$\tau_{\text {MSAM }}=\frac{1}{k_{4}[\mathrm{OH}]+k_{\mathrm{dd}}+k_{\text {het }}}$.

Using our overall rate coefficient, $k_{4}=1.4 \times$ $10^{-13} \mathrm{~cm}^{3}$ molec. ${ }^{-1} \mathrm{~s}^{-1}$, for the title reaction and taking a diel-averaged $\mathrm{OH}$ concentration of $1 \times 10^{6}$ molec. $\mathrm{cm}^{-3}$, we can use Eq. (2) to calculate a first-order loss rate constant of $k_{4}[\mathrm{OH}]=1.4 \times 10^{-7} \mathrm{~s}^{-1}$. Which is equivalent to a lifetime of $\approx 80 \mathrm{~d}$.

MSAM is highly soluble and a dry deposition velocity of $\approx 1 \mathrm{~cm} \mathrm{~s}^{-1}$ to the ocean has been estimated (Edtbauer et al., 2019). Combined with a marine boundary height of $\approx 750 \pm$ $250 \mathrm{~m}$, this results in a loss rate coefficient of $1.3 \times 10^{-5} \mathrm{~s}^{-1}$ or a lifetime with respect to uptake to the ocean of less than $1 \mathrm{~d}$. Wet deposition is also likely to play a role, which may limit the MSAM lifetime to days under rainy conditions and to weeks in dry regions.

To a first approximation the heterogeneous loss rate of a trace gas to a particle is given by

$k_{\text {het }}=0.25 \gamma \bar{c} A$,

where $\gamma$ is the uptake coefficient which represents the net efficiency (on a per collision basis) of transfer of MSAM from the gas phase to the particle phase, $\bar{c}$ is the mean molecular velocity of MSAM $\left(\sim 26000 \mathrm{~cm} \mathrm{~s}^{-1}\right)$, and $A$ is the surface area density of particles $\left(\mathrm{cm}^{2} \mathrm{~cm}^{-3}\right)$ for which a typical value in lightly to moderately polluted regions would be $1 \times 10^{-6} \mathrm{~cm}^{2} \mathrm{~cm}^{-3}$. A rather low uptake coefficient of $\sim 2 \times 10^{-5}$ would then be sufficient to compete with MSAM loss due to reaction with $\mathrm{OH}$, but a value of $2 \times 10^{-3}$ would be necessary to compete with dry deposition.

\section{Conclusions}

The rate coefficient for reaction of methane sulfonamide (MSAM) with $\mathrm{OH}$ was determined using the relative rate method as $(1.4 \pm 0.3) \times 10^{-13} \mathrm{~cm}^{3}$ molec. ${ }^{-1} \mathrm{~s}^{-1}$. The major, stable, quantifiable sulfur- and nitrogen-containing end products of the reaction are $\mathrm{SO}_{2}$ and $\mathrm{HNO}_{3}$ with molar yields of $(0.96 \pm 0.15)$ and $(0.62 \pm 0.09)$, respectively. $\mathrm{CO}$ and $\mathrm{CO}_{2}$ are the dominant carbon-containing products. $\mathrm{N}_{2} \mathrm{O}$ and $\mathrm{HC}(\mathrm{O}) \mathrm{OH}$ were also observed at lower yields of $(0.09 \pm 0.02)$ and $(0.03 \pm 0.01)$, respectively. The end products (and the low rate coefficient) are consistent with an initial abstraction by $\mathrm{OH}$ from the $\mathrm{CH}_{3}$ group. Based on our results MSAM has an atmospheric lifetime with respect to loss by reaction with $\mathrm{OH}$ of about $80 \mathrm{~d}$, indicating that other processes (e.g. deposition) will likely dominate.

Data availability. The rate coefficients measured during this experimental study are listed in Table 2 .

Supplement. The supplement related to this article is available online at: https://doi.org/10.5194/acp-20-2695-2020-supplement.

Author contributions. The experiments and data analysis were carried out by $\mathrm{MB}$ and $\mathrm{DA}$. The preparation of the paper was performed by $\mathrm{MB}$ and JNC, with contributions from DA, JL, JW, and AE. 
Competing interests. The authors declare that they have no conflict of interest.

Financial support. The article processing charges for this openaccess publication were covered by the Max Planck Society.

Review statement. This paper was edited by James B. Burkholder and reviewed by two anonymous referees.

\section{References}

Andreae, M. O.: Ocean-atmosphere interactions in the global biogeochemical sulfur cycle, Mar. Chem., 30, 1-29, https://doi.org/10.1016/0304-4203(90)90059-1, 1990.

Andreae, M. O. and Crutzen, P. J.: Atmospheric aerosols: Biogeochemical sources and role in atmospheric chemistry, Science, 276, 1052-1058, https://doi.org/10.1126/science.276.5315.1052, 1997.

Atkinson, R., Baulch, D. L., Cox, R. A., Crowley, J. N., Hampson, R. F., Hynes, R. G., Jenkin, M. E., Rossi, M. J., and Troe, J.: Evaluated kinetic and photochemical data for atmospheric chemistry: Volume $\mathrm{I}-$ gas phase reactions of $\mathrm{O}_{x}, \mathrm{HO}_{x}$, $\mathrm{NO}_{x}$ and $\mathrm{SO}_{x}$ species, Atmos. Chem. Phys., 4, 1461-1738, https://doi.org/10.5194/acp-4-1461-2004, 2004.

Atkinson, R., Baulch, D. L., Cox, R. A., Crowley, J. N., Hampson, R. F., Hynes, R. G., Jenkin, M. E., Rossi, M. J., Troe, J., and IUPAC Subcommittee: Evaluated kinetic and photochemical data for atmospheric chemistry: Volume II - gas phase reactions of organic species, Atmos. Chem. Phys., 6, 3625-4055, https://doi.org/10.5194/acp-6-3625-2006, 2006.

Barnes, I., Solignac, G., Mellouki, A., and Becker, K. H.: Aspects of the Atmospheric Chemistry of Amides, Chem. Phys. Chem., 11, 3844-3857, https://doi.org/10.1002/cphc.201000374, 2010.

Bates, T. S., Lamb, B. K., Guenther, A., Dignon, J., and Stoiber, R. E.: Sulfur emissions to the atmosphere from natrural sources, J. Atmos. Chem., 14, 315-337, https://doi.org/10.1007/bf00115242, 1992.

Borduas, N., da Silva, G., Murphy, J. G., and Abbatt, J. P. D.: Experimental and Theoretical Understanding of the Gas Phase Oxidation of Atmospheric Amides with OH Radicals: Kinetics, Products, and Mechanisms, J. Phys. Chem. A, 119, 4298-4308, https://doi.org/10.1021/jp503759f, 2015.

Bunkan, A. J. C., Srinivasulu, G., Amedro, D., Vereecken, L., Wallington, T. J., and Crowley, J. N.: Products and Mechanism of the $\mathrm{OH}$ initiated photo oxidation of perfluoro ethyl vinyl ether, $\mathrm{C}_{2} \mathrm{~F}_{5} \mathrm{OCF}=\mathrm{CF}_{2}$, Phys. Chem. Chem. Phys., 20, 11306-11316, 2018.

Burkholder, J. B., Sander, S. P., Abbatt, J., Barker, J. R., Huie, R. E., Kolb, C. E., Kurylo, M. J., Orkin, V. L., Wilmouth, D. M., and Wine, P. H.: Chemical Kinetics and Photochemical Data for Use in Atmospheric Studies, Evaluation No. 18, JPL Publication 15-10, Jet Propulsion Laboratory, Pasadena, available at: http: //jpldataeval.jpl.nasa.gov (last access: 27 February 2020), 2015.

Butkovskaya, N. I. and Setser, D. W.: Branching Ratios and Vibrational Distributions in Water-Forming Reactions of $\mathrm{OH}$ and OD
Radicals with Methylamines, J. Phys. Chem. A, 120, 6698-6711, https://doi.org/10.1021/acs.jpca.6b06411, 2016.

Charlson, R. J., Lovelock, J. E., Andreae, M. O., and Warren, S. G.: Oceanic phytpoplankton, atmospheric sulfur, cloud albedo and climate, Nature, 326, 655-661, https://doi.org/10.1038/326655a0, 1987.

Crowley, J. N., Saueressig, G., Bergamaschi, P., Fischer, H., and Harris, G. W.: Carbon kinetic isotope effect in the reaction $\mathrm{CH}_{4}+$ $\mathrm{Cl}$ : a relative rate study using FTIR spectroscopy, Chem. Phys. Lett., 303, 268-274, 1999.

Deng, G. H., Wu, Z., Li, D. Q., Linguerri, R., Francisco, J. S., and Zeng, X. Q.: Simplest N-Sulfonylamine $\mathrm{HNSO}_{2}$, J. Am. Chem. Soc., 138, 11509-11512, https://doi.org/10.1021/jacs.6b07966, 2016.

Dillon, T. J. and Crowley, J. N.: Direct detection of OH formation in the reactions of $\mathrm{HO}_{2}$ with $\mathrm{CH}_{3} \mathrm{C}(\mathrm{O}) \mathrm{O}_{2}$ and other substituted peroxy radicals, Atmos. Chem. Phys., 8, 4877-4889, https://doi.org/10.5194/acp-8-4877-2008, 2008.

Edtbauer, A., Stönner, C., Pfannerstill, E. Y., Berasategui, M., Walter, D., Crowley, J. N., Lelieveld, J., and Williams, J.: A new marine biogenic emission: methane sulfonamide (MSAM), DMS and $\mathrm{DMSO}_{2}$ measured in air over the Arabian Sea, Atmos. Chem. Phys. Discuss., https://doi.org/10.5194/acp-2019-1021, in review, 2020.

Falbe-Hansen, H., Sorensen, S., Jensen, N. R., Pedersen, T., and Hjorth, J.: Atmospheric gas-phase reactions of dimethylsulphoxide and dimethylsulphone with $\mathrm{OH}$ and $\mathrm{NO}_{3}$ radicals, $\mathrm{Cl}$ atoms and ozone, Atmos. Environ., 34, 1543-1551, 2000.

Frisch, M. J., Trucks, G. W., Schlegel, H. B., Scuseria, G. E., Robb, M. A., Cheeseman, J. R., Scalmani, G., Barone, V., Mennucci, B., Petersson, G. A., Nakatsuji, H., Caricato, M., Li, X., Hratchian, H. P., Izmaylov, A. F., Bloino, J., Zheng, G., Sonnenberg, J. L., Hada, M., Ehara, M., Toyota, K., Fukuda, R., Hasegawa, J., Ishida, M., Nakajima, T., Honda, Y., Kitao, O., Nakai, H., Vreven, T., Montgomery Jr., J. A., J. Peralta, E., Ogliaro, F., Bearpark, M., Heyd, J. J., Brothers, E., Kudin, K. N., Staroverov, V. N., Kobayashi, R., Normand, J., Raghavachari, K., Rendell, A., Burant, J. C., Iyengar, S. S., Tomasi, J., Cossi, M., Rega, N., Millam, J. M., Klene, M., Knox, J. E., Cross, J. B., Bakken, V., Adamo, C., Jaramillo, J., Gomperts, R., Stratmann, R. E., Yazyev, O., Austin, A. J., Cammi, R., Pomelli, C., Ochterski, J. W., Martin, R. L., Morokuma, K., Zakrzewski, V. G., Voth, G. A., Salvador, P., Dannenberg, J. J., Dapprich, S., Daniels, A. D., Farkas, Ö., Foresman, J. B., Ortiz, J. V., Cioslowski, J., and Fox, D. J.: Gaussian 09, Gaussian, Inc., Wallingford CT, 2009.

Groß, C. B. M., Dillon, T. J., Schuster, G., Lelieveld, J., and Crowley, J. N.: Direct kinetic study of $\mathrm{OH}$ and $\mathrm{O}_{3}$ formation in the reaction of $\mathrm{CH}_{3} \mathrm{C}(\mathrm{O}) \mathrm{O}_{2}$ with $\mathrm{HO}_{2}$, J. Phys. Chem. A, 118, 974985, https://doi.org/10.1021/jp412380z, 2014.

Halls, M. D., Velkovski, J., and Schlegel, H. B.: Harmonic frequency scaling factors for Hartree-Fock, S-VWN, B-LYP, B3LYP, B3-PW91 and MP2 with the Sadlej pVTZ electric property basis set, Theor. Chem. Acc., 105, 413-421, 2001.

Ianni, J. C.: Kintecus v. 5.5, available at: http://www.kintecus.com (last access: 27 February 2020), 2015.

IUPAC: Task Group on Atmospheric Chemical Kinetic Data Evaluation (Ammann, M., Cox, R. A., Crowley, J. N., Herrmann, H., Jenkin, M. E., McNeill, V. F., Mellouki, A., Rossi, M. J., Troe, 
J., and Wallington, T. J.), available at: http://iupac.pole-ether.fr/ index.html, last access: October 2019.

Kohlmann, J.-P. and Poppe, D.: The tropospheric gas-phase degradation of $\mathrm{NH}_{3}$ and its impact on the formation of $\mathrm{N}_{2} \mathrm{O}$ and $\mathrm{NO}_{x}$, J. Atmos. Chem., 32, 397-415, 1999.

Onel, L., Blitz, M., Dryden, M., Thonger, L., and Seakins, P.: Branching Ratios in Reactions of $\mathrm{OH}$ Radicals with Methylamine, Dimethylamine, and Ethylamine, Environ. Sci. Technol., 48, 9935-9942, https://doi.org/10.1021/es502398r, 2014.

Ray, A., Vassalli, I., Laverdet, G., and LeBras, G.: Kinetics of the thermal decomposition of the $\mathrm{CH}_{3} \mathrm{SO}_{2}$ radical and its with $\mathrm{NO}_{2}$ at 1 Torr and $298 \mathrm{~K}$, J. Phys. Chem., 100, 8895-8900, https://doi.org/10.1021/jp9600120, 1996.
Remko, M.: Theoretical study of molecular structure and gas-phase acidity of some biologically active sulfonamides, J. Phys. Chem. A, 107, 720-725, https://doi.org/10.1021/jp026980m, 2003.

Spiro, P. A., Jacob, D. J., and Logan, J. A.: Global inventory of sulfur emissions with 1-degree $\times$ 1-degree resolution, J. Geophys. Res.-Atmos., 97, 6023-6036, https://doi.org/10.1029/91jd03139, 1992. 